\title{
HUMANISTIC AND TECHNICAL EDUCATION IN AntiQuity AND The Middle Ages
}

\author{
KRASIC, S.
}

\begin{abstract}
The study deals with the beginnings and development of humanistic and technical knowledge primarily in ancient Greece and Rome until the end of the Middle Ages. It also analyzes school as an organized social institution for transfer of knowledge and scientific insights. Numerous Greek philosophers, scientists and intellectuals founded their schools in which program was not set but it varied from one teacher to another, from one school to another. Number of subjects learnt in these schools gradually came to number seven: grammar, logic, rhetoric, arithmetic, geometry, astronomy and music. These were ", seven liberal arts" (septem artes liberales) which were practiced by "free" (wealthy) people as opposed to „unfree" activities (manual work) performed by lower social classes or slaves. Teaching program of the old Greeks was the basis of entire education until the end of the Middle Ages (15th century). It was accepted particularly well by the Romans who as opposed to the Greeks paid more attention to technical arts which is attested by many novelties particularly in architecture which had to depict and represent the strength of the Empire. Therefore their builders had to find solution which surpassed everything known until that point. This magnificent civilization received heavy blow during the Great Migration period from the 5th to 8th centuries. In the turmoil of raids of new ,, barbaric" nations torch of Greco-Roman culture and science was almost extinguished. Schools disappeared after the collapse of organized state administration. New Europe which was born with the Frankish Empire was forced to start everything anew. At the beginning it searched for a model in antiquity, but gradually many novelties were introduced, particularly in the field of technical solutions. People started to pay same attention to physical labour as to humanistic (intellectual) disciplines which changed society profoundly alongside using new sources of energy. Many of these inventions were accepted from other, particularly eastern populations - Arabs, Persians, Indians and Chinese. But the Europeans knew how to recognize, accept and develop these things making them civilizational heritage of all others. Development of technical culture was accompanied by development of schooling enriched with new school disciplines which led to founding of universities in the 12th and 13th centuries as an original European invention no other civilization knew of. Owing to universities Europe finally left its inherited stagnancy starting to take the leading role in the world of science and technics.
\end{abstract}

Key words: knowledge, science, school, grammar, rhetorics, dialectics, arithmetics, geometry, astronomy, technics, technical sciences, universities
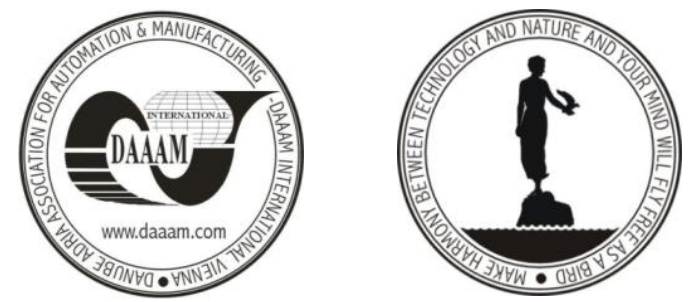

Authors' data: Univ. Prof. Dr. Sc. Emeritus Krasic, S[tjepan], Dominikanski samostan, Dubrovnik, Svetog Dominika 4, HR-20000 Dubrovnik, Croatia, Email: krasic@ hotmail.it

This Publication has to be referred as: Krasic, S[tjepan] (2013) Humanistic and Technical Education in Antiquity and the Middle Ages, Chapter 01 in DAAAM International Scientific Book 2013, pp. 001-052, B. Katalinic \& Z. Tekic (Eds.), Published by DAAAM International, ISBN 9783-901509-94-0, ISSN 1726-9687, Vienna, Austria

DOI: 10.2507/daaam.scibook.2013.01 


\section{Humanistic and Technical Education in Antiquity}

\subsection{Dawn of Scientific Thought of Humanity}

Origins (absolute beginnings) of many things, as well as knowledge, are lost in the darkness of past times. Certain kinds of knowledge and scientific disciplines can be found in all, or almost all humans and civilizations: Greeks, Egyptians, populations in Mesopotamia, India and China, even in pre-Columbian America. For instance around 3000 years BC Hindus studied phonetics, grammar, exegesis, logic, mathematics, astronomy and some other scientific disciplines as propaedeutics for understanding the Vedas. It is quite certain that the ancient Egyptians definitely had to be acquainted with sciences such as mathematics, geometry and astronomy, or the art of music, painting, sculpture and other arts, particularly mechanics, construction techniques etc. as they built magnificent pyramids more than 4 or 5 thousand years ago and determined calendar of the Nile floods. Knowledge and cognition are important human characteristics which determine a man distinguishing him from the surrounding world. They make him free primarily from the slavery of darkness of ignorance which obstructs his vision and from the slavery of prejudice which are only different names for the same darkness.

We do not want to diminish or deny merit or importance to any nation but we can state that the European or western civilization traces its origins from ancient Greece. Although the Greeks inherited or accepted some knowledge from other nations, they knew how to enrich it with something of their own. This ,something“ was great enough to make them a nation which probably indebted entire humanity with their achievements more than any other. Their ability of abstract thinking, thoroughness and critical approach in the study of nature and man could not be equaled over the course of history. Due to stregth of their mind in only three centuries (6th -3 rd cent. BC) they set humanity free from myths and superstitions enabling it to make reasonable vision of a man and world around him lying in that way foundations of what we refer to as scientific view of the world. Their thinkers, frequently without consulting with one another, seemed to compete who would deep diver in the sea of discovering secrets hidden in a man and world around him.

Although most of components of the general civilization existed for thousands years in different parts of the world it is doubtless that the Greeks made the greatest progress. By pure strength of mind they set humanity free from primitive beliefs, traditional prejudice and irrational conceptions characteristic of the populations on lower stage of civilizational development and enabled rational Prometean „conquering of the sky“ i.e. understanding manifestational world. Ancient Greek religion was never crystallized as Judaism, Christianity or Islam in terms of monoteistic religion nor did it have sacred books or deities who determined human fate. While others divinized nature and its phenomena, Greeks humanized them. Their theogony as described by „forefathers“ of Greek historical memory Homer and somewhat younger Hesiod (ca. 7th century BC) were gods and goddesses residing on not very high Mount Olympus. Although omnipotent and immortal they were only idealized human figures with pronounced human characteristics, faults and virtues. However there is insurmountable gap between gods and men: gods have superhuman 
powers and immortality. They are important as they symbolize certain human characteristics: strength (Zeus), beauty (Aphrodite and Hermes), intelligence (Apollo) etc. which are at the same time purely human ideals. In certain preserved statues representing young athletes it is not easy to determine whether it was Apollo or personification of youth, strength and beauty. Apollo whose seat was at Delphi was a patron of strength, youth, art, medicine, music, poetry and rhetorics. Aim of art was to represent beauty of idealized human or divine figure. Relation of Greek deities with humans is neither personal nor intimate but formal and external as relation of a king with his subjects. Human aspiration to achieve these characteristics is represented in the myth about Prometheus who as a mortal man „steals“ secret of „fire“ (knowledge, power) which the Olympian gods enviously kept for themselves.

In other words ideal of old Greeks was to obtain natural secrets and powers or at least understand how this visible world works. While they remained on this „primitive“ level in their considerations of gods, they went further than any other nation in understanding of the world. Light of reason with which they came to idea to understand nature and explain it with their own and general laws was first ignited in Ionia and later elsewhere where enlightened individuals started asking questions which still represent challenge for human mind: wherefrom all this, what is it of and why? Democritus (460-370) was first to come to idea that visible world was made from tiny, invisible and inseparable particles which he called atoms; Socrates (469399) with his seemingly naive but very deep questions forced others to think unwillingly so he was called „the gadfly of Athens“; Plato (427-347) raised such thoughts to metaphysical level on the basis of which task of philosophy was to realize vison of eternal and perfect forms which represent true values of the universe; Aristotle (384-322) was concentrated on studying facts creating in his quest of truth formal logic. These are only some representatives of the Greek scientific and philosophic thought who still did not clearly distinguish areas of purely philosophic speculation and science in the strict sense of the word: scientific thought was involved with speculations about creation and structure of the universe, and philosophy had pretensions to explore it. In accordance with this understanding philosophers were at the same time scientific researchers and people who tried to understand deep meaning of evrerything that exists. But it was not harmful for general progress. There are many achievements of Greek thinkers in art, architecture, literature, philosophy and other disciplines which had set merits of western art for more than two thousand years. Their influence was so great that in the west classical art was considered as not only highest but also only „real“ art of the civilized man.

But Greek achievements in the purely intellectual field are often even more exceptional. They not only invented science and philosophy; they were the first to write history from ordinary annals; they discussed freely about the nature of the world, meaning of life, state system and started to organize foundation of schools for their fellow-citizens finding in their poet Homer ideal expression of their culture and identity. His epics were a basic source of knowledge about the gods, history, language, culture and customs to all generations of the Greeks, to put it simply similar as the Bible for the Christians or the Koran for the Muslims. 
In order to comprehend understanding of physics by the ancient Greeks it is necessary to understand their ideational background. Their creative background is different from the one in modern scientist. Presently children grow with mechanics which makes us think of machines by its very name. They are used to cars and planes, computers and other wonders of modern electronics. They cannot even start to think that car contains a sort of horse or that a plane flies since it has wings of a bird with magical powers.

\subsection{Ionia - Cradle of the Greek Civilization}

The first and most important teacher of all Greeks was legendary blind poet Homer who was supposed to have lived in the 8th century BC. Leaving aside discussions about his actual historical existence and authorship of the epic poems Iliad and Odyssey which are ascribed to him we would just like to say that he is considered as the founder of entire Greek culture in the earliest tradition. From his epic poems we can conclude that culture in the period about which he writes was a privilege of a sort of warrior aristocracy. His heroes are not raw soldiers, warriors and prehistoric warriors but a kind of knights who served at royal courts and enjoyed great respect alongside priests when they offered sacrifices. They were raised as knights and acted in precisely determined code of honor, in wars and mutual duels they respected honor of their enemies, they treated ladies as gentlemen, which implies adequate upbringing. Achilles, one of Homer's heroes has several excellent teachers. One of them, Chiron teaches Achilles sport and chivalry competition, hunting, riding, sword-play, spear throwing, lyre playing and even surgery and pharmacy. Achilles treats his old teachers which were entrusted with his upbringing with respect, as a true knight, he accepts their advice and executes their instructions.

Homer's hero is a disciple who accepts from his teachers everything that a knight and warrior must know: he must possess all knowledge and skills. In his upbringing it is easy to notice two basic factors: technique which a disciple must possess in handling weapons and musical instruments and ethics which determines his relations with others. Only technical education can make a good warrior from a young man, and ethics i.e. upbringing refines a warrior making him a knight, who had to have manners, know life and world, and have wisdom. Technical knowledge necessary therein includes handling weapons, sport, chivalry games, oratorial skills (ability to speak properly and eloquently) and music skills (singing, lyre, dancing) etc. All these technical elements can be found in classical Greek upbringing. In specific cities-states (polis) these elements were enriched with many other skills and knowledge. In that way physical education, technical skills, warrior spirit and iron discipline were dominant in Sparta, and love for knowledge, tendency to intellectual thinking and wish for competition in Athens.

Homer was, as explained later by Plato, the first teacher of ancient Greece who laid foundations to its mentality and identity and provided directions to entire later development of intellectual upbringing. His epic poems which many children in Greece could recite by heart were appreciated not only as master-pieces of literary art but also as basic manuals from which literacy was taught, as sources of inspiration and knight's ethics. They were also used to learn how to behave properly and to 
develop love for knowledge. Children identified themselves with his heroes and formed their views of life.

\subsection{Creation of Greek Scientific Thought}

Greek scientific thought in broad meaning of the word was born in Ionia. This was the place where influences of cultures and civilizations of eastern Mediterranean and Middle East, primarily Egyptian and Mesopotamian civilization mixed. Ionians had numerous connections with Egypt and Mesopotamia from which they learnt and accepted various notions and admitted to do so. It is more than likely that the Greeks learnt and accepted from these civilizations many things from the area of technology such as making ceramic objects, weaving, metal processing etc. While other nations were satisfied with practical use of these skills, the Greeks were tempted by their insatiable curiosity to ask for reasons and causes. In this quest for causes they added theory to the practice, mastered general terms and practiced recognizing generals laws. That is their specific contribution to human thought. In this encounter, mutual permeation and sometimes even conflict of mentioned civilizations, first sparkle of philosophy and science in broad sense of the word appeared which in time turned into a real flame on which humanity still gets warm and whose flame illuminates the darkness of ignorance.

Ionia was not only homeland of the legendary blind poet, pride of Greece but also a cradle of philosophy and science. At the beginning of the 6th century the Miletians were the first who started to understand that mythological explanations of the world do not satisfy their spirit so that they tried to explain its origin with reason believing that general and predictable laws rule the world, not coincidences or whims of gods. Something was born that might be referred to as the beginning of European philosophy. The first thinker who is known to have posed questions about the origin, causes and sense of manifestational world attempting to find a rational answer was Thales of Miletus, man with great practical gift which is listed among seven sages by Greek tradition. He concluded that world was created from water as he understood that humidity was necessary for life. Historian Herodotus (ca. 484-430) ascribes to him merits of predicting a Sun eclipse which - as it seems - happened in $585 \mathrm{BC}$, that he knew how to measure height of the Egyptian pyramids on the basis of their shadow, distance of a ship at sea using triangulation. It was the beginning of science and philosophy and of the Ionic philosophical school, first of the kind in history.

Thales' successor as the head of the school was his disciple philosopher Anaximander (ca. 610-640) who placed one neutral thing, ,indetermined" and „infinite", as true principle of changes in the world, which produces individual things as its opposite (warm - cold, damp - dry). Living beings were created as heat (Sun) heated the water and men were similar to fish. This differentiation process finally ends in integration and returning of individual to original general. Anaximander composed the first map and model of sky after which Earth has shape of cylinder floating in the center of the world. Living beings including humans developed from lower organisms anticipating in that way later theory of evolutionism.

Third philosopher from this school was Anaximenes (ca. 585- 523) after whom principle of everything is air which is in constant movement transforming from one 
form into another, from simpler to more complex. All complex bodies are formed by joining these elements.

Persian occupation of the Greek cities on the Asia Minor coast, particularly Miletus (499 BC) which led to Ionic rebellion and was a cause of lengthy wars with the Greeks, resulted in migrations of educated Greeks westwards who seeked shelter in Greece, particularly on islands (Lesbos, Hios, Samos, Chios, Kos, Delos, Rhodos etc.) in the Ionian Sea, in the south of the Apennine Peninsula (Taranto, Metaponto, Sybaris, Kroton, Elea, Paestum, Neapolis), on the island of Sicily (Syracuse, Catania, Zancle, Acragas, Gela, Selinunte) etc. They continued their work there and founded many famous philosophical schools which questioned laws and sense of manifestational and non-manifestational world. In their considerations and explorations manifestational world and world of ideas went side by side as well as physics and metaphysics as parts of one whole or front and back side of one unique reality.

Pythagoras (ca. 571 - ca. 497 BC) from the island of Samos probably takes the most prominent position among the first philosophers and scientists. While travelling on the Mediterranean he founded a peculiar philosophical school in Croton in southern Italy. He directed philosophy in a new direction making it a basis of life in a fraternity whose aims were not only philosophical but also political. Music was powerful medium of purifying human life which demands harmony of inner and outer life. As an excellent musician he played lyre using music to cure patients (musicotherapy). He believed that the world was ,harmony“ which was confirmed by intervals of musical scales and that everything in universe can be expressed with numbers.

His observation that strings of musical instruments make tones in harmony when coefficients of lengths of these strings were whole numbers led to discovering regularities in music and creating mathematical theory of music. He was first to use numbers to mark relations between tones of consonant intervals. After understanding that wire twice as short gives a higher tone for an octave, he marked octave relation with ratio of $2: 1$. In the same way he discovered ratio of parts of wire in a quint ( 3 : 2 ) and quart $(4: 3)$. He made musical scale from quint relations. Under influences of magical beliefs Pythagoras saw symbolical values in numbers 1, 2, 3, 4 relating them with seasons and cardinal directions. In three intervals of tuned wire he saw three ways of human life. In that way, by connecting real and unreal, reality and religion he searched the way towards purity of soul, believing that he would find it with help of music and ascetic life.

In other words music made him and his disciples conclude that numbers ruled the universe, particularly group $1-4$ (so-called tetractys). Although this is pure speculation, tuned wire played an important role in the Greek philosophical thinking from this period. Notion of harmony in terms of balance, harmonizing and combining the opposites as long and short, high and low, warm and cold is a concept of average or middle way in ethics and theory of four temperaments are important achievements of Pythagoras' thinking. It is very likely that mentioned discoveries in music led to an idea that all things were numbers ("everything is number"). Since they control structure of the system of tones and rhythms, their understanding offers a key to understanding entire spiritual and physical world. That means that we need to 
discover numbers in things in order to understand the world around us. As soon as we do, we have reached power over the world.

Pythagoras discovered famous geometrical theorem that states that in the rightangled triangle the area of the square on the hypotenuse (the side opposite the right angle) is equal to the sum of the areas of the squares of the other two sides. His discovery that the Earth is spherical is just as important, but he nevertheless did not manage to discover the heliocentric system. This discovery is ascribed to Aristarchus of Samos $(310-239$ BC). This does not reduce his geniality as a pioneer of mathematics and exact research in physics and creator of one of the most original philosophical-scientific systems which laid the foundations of the Greek scientific thought and western science. Owing to him, Greek philosophy is as old as the rational science in which mathematics takes a crucial place.

Pythagoras was the first to exhibit interest in mathematics out of pure love for knowledge, not in an attempt to make use of it. Egyptians had certain mathematical knowledge but only to the extent to allow them to build pyramids and temples or measure their fields. The situation was similar with other nations. In philosophy he turned attention from matter to form and in anticipation of modern physics he tried to explain nature with mathematical principles. Due to misunderstandings which he encountered in Crotone he moved to Metaponte where he stayed until death. Although his school promoted certain religious views based on metaphysics of a number in line with Greek religion (Orphic concepts of afterlife, randomness of existence, necessity of escaping the social position determined by birth etc.), it incited scientific and particularly mathematical revolution.

It is quite natural that philosophical questions are born on the edge of scientific research. From this period arithmetic and geometry under influences of Pythagoreanism started to play irreplaceable role in Greek philosophy primarily because mathematics as opposed to philosophy was an exact science in which problems were posed in a clear and logical way and answers are clear and precise. Secondly mathematics as such started to serve as propaedeutics for the study of philosophy. Thirdly in mathematics there is a set procedure of proving, which is a great Greek invention. Fourthly, once correctly understood conclusions of mathematical proof eliminate any doubt. To put it simply, mathematics was the first and only science in the strict sense of the word. Other sciences in the strict sense of the word are sciences only if they come close to mathematics. Therefore it is not accidental that many great philosophers were excellent mathematicians.

It is surprising how many fundamental problems were noticed, solved or recognized by the Greek mathematicians in the 5th and 4th centuries BC although they had very modest scientific instruments, all the more as it was not imposed by everyday life. Most problems they encountered were theoretical and their solution was an expression of pure pursuit for scientific truth lacking any practical use and ideal of knowledge for knowledge's sake. While „practical mathematics“ in other nations (Egyptians, Babylonians etc.) was aimed at solving specific problems and as such necessarily approximate, Greeks looked for precise solutions which could only be provided by scientific mathematics based on logical thought and rational explanation. This scientific seal was printed on mathematics once and for all making it only exact science in the strict sense of the word. 


\subsection{Athens - Major Intellectual City in Greece}

Athens is believed to be the cradle of Greek scientific and philosophic thought as it paid more attention to schooling than any other city-state (polis) making foundations for entire later school education. Schools are mentioned here as early as the 7th century. But until the 5th century most children obtained only education they could get at home. Athenians were the first to replace warriors' way of life with culture in the strict sense of the word. In their city-state from the earliest time there was a kind of obligatory education existed which included studying arithmetics, geometry, astronomy, grammar and music as introduction to philosophy which was a synthesis of all mentioned disciplines which was crucial for progress of the entire state.

But it was only with Plato (427-347) that schooling developed as never before. As one of the greatest mind ever and disciple of Socrates who proclaimed knowledge as virtue, he emphasized need of founding schools more than anyone else. „If Athens has poor shoe-makers, its citizens will walk bare-foot. It Athens has poor teachers, there will be no Athens. " Consistent to this belief he founded a philosophical school in Athens or an educated society which was called Academy after the Athenian hero Akademos. It was the first and one of best organized schools in history of European civilization. Impressed with extratemporal world of mathematics discovered by Pythagoreans he applied his rules to ethical and physical field. After the model of traditional subjects of Pythagorean schools, lectures were not limited to philosophy but they also included arithmetics, planimetry, trigonometry, astronomy and music offering its students almost entire knowledge at the time. Particular attention was paid to mathematics due to strong influences of Pythagorean heritage. Original aim of schooling in the Academy was philosophical-scientific education. Although Plato aimed at education of statesmen and public employees, his method did not consist of teaching some disciplines which had some immediate and practical use such as teaching rhetorics but in inciting of indifferent dealing with science. Mathematics played crucial role in this process. He was impressed by extratemporal world of mathematics discovered by the Pythagoreans so he applied rules of this world on ethical and physical fields of human life. Mathematics was a science directed at extra-sensory phenomena and achieving universal and eternal truth which incited him to attempt to discover the essence of actual structure of mathematical science. This is something more than regular "philosophy of mathematics“ which attempts to determine general terms of this scientific discipline. Peak of education was in philosophy and alienating disciples from variability of manifestational world and their directing to the unchangeable and important hiding behind, to the essence, and understanding general data and regularities, training for critical and rational thinking and understanding so that people may learn how to think critically by using their reason.

Plato was not satisfied with teaching only but he also studied science of numbers which were a part of arithmetics. On the basis of heritage of the philosopher and mathematician Hippias of Elis (5th century BC) he ascribed important educational role to mathematics. Nobody sould ignore mathematics if he aims at being considered a man and not ,a pig for fattening“. He mentions this role of mathematics in his works repeatedly. Allegedly he even put a sign at the entrance of the Academy:"Let 
no-one ignorant of geometry enter here!“. Interest for mathematics should be evoked through games with the children at the earliest age as mathematics is an important component of everyday life so he introduced it into every day life, after the Egyptian model, particularly in crafts, trade, military skills, agriculture, navigation etc. These first mathematical notions as practical as they may be were supposed to serve as an introduction into a much deeper comprehension of the world. He paid just as much attention to applied geometry in calculating superficies, length and capacity of a certain body, and in astronomy he studied way of making calendar. No other discipline could be compared with it. Its role was to awaken the spirit in order to obtain easiness of thinking and concluding. In that way he introduced study of mathematics as an unavoidable school subject from the earliest age to maturity.

Not everyone could reach this level. Most talented disciples should be recognized and supported which meant introduction of selection of the able and less able which remained basis of all later exams and contests, including the modern ones. Mathematics was the best discipline to select the ablest and to develop natural abilities in order to become philosophers one day. It will lead to selection of future philosophers, it will form and prepare them for future tasks which was an important factor of its „educational preparation“. By studying mathematics pupils developed ability of deeper understanding of reality, memory and self-confidence not to be discouraged when they face difficulties in studying and understanding world around them.

Entire 7th book of his State deals with science. It starts with a myth about a cave: mathematics is a primary instrument of „converting“ the soul, expression of inner need with which it awakens in real light and becomes able to consider not „shadows of real things“ but „true reality“. But there is long way to this point. Years of study and consideration are necessary for becoming a true philosopher (scholar). Only after 30 years of study and consideration of mathematics one can reach such stage of mental and educational development. He has to give up sensitory instruments in order to reach truth of the Essence. Regardless of the fact that such individuals are extremey rare, only the persistent ones can come to understand fertile but dangerous art called dialectics. Such individuals needed five more years of study to come into possession of the only instrument leading to complete truth. But that was not the end of philosophic culture in the strict sense of the word. Apprentice had to face complicated city life for 15 more years in order to obtain additional experience, end his struggle with temptations and obtain moral education. Only at the age of fifty those who live to that age and overcome all difficulties can finally reach the aim: „contemplation of the Good in themselves“. So it takes fifty years to become a „man“!

\subsection{Plato and Isocrates Founders of Two Various School Systems}

As opposed to Plato's ideally conceived moral and political-educational program, Isocrates $(436-338 \mathrm{BC})$, a philosopher and one of the ten best orators in antiquity, offered much shorter and simpler program of school education. He was the Eye for 50 years (393-338), he had school of rhetorics in Athens which as opposed to Plato's Academy was open for everyone and it enjoyed great popularity. Education in it lasted for only 3-4 years and costed 1000 drachmas. About 100 disciples from all 
regions of Greece attended the school. Rhetorics with him became means of action, particularly political action which is used by a thinker to present his opinion and to affect the public. Through this kind of public performance rhetorics got new meaning which will be particularly pronounced in the Hellenistic and Roman period and which affected forming of the study significantly.

Isocrates introduced into rhetorics many elements which were characteristic of writers, taking care of their practical efficiency. Good orator had to know how to speak well, correctly and convincingly which is why he had to master the technique of discussing and persuading. He raised a fair number of his pupils in this spirit. While Plato's upbringing was based on emphasizing the importance of truth, Isocrates based it on strength, i.e. convincingness of his words. A word distinguishes a man from an animal and it was a prerequisite of any kind of progress in legal, artistic or everyday field enabling man to realize justice, and promote civilization or culture.

Philosophical science according to Plato had no practical purpose. It may have had one if there was an ideal state. Since there is no such state, philosopher is forced to deal with himself, non-existant world and imaginary problems. As opposed to Plato, Isocrates was much more specific and practical. Learned man is someone who can propose good solution of a specific problem. Rhetorics was a general educational discipline which contained not only theory of speech and style but also basics of moral, philosophy and statesmanship necessary for successful life in a state community. In Isocrates' school subjects later called grammar and philology were taught as a basis of rhetorics and everything necessary for an orator as a writer and politician in order to learn how to speak eloquently and convincingly: philosophy, science and art and ability to use words smartly in solving practical problems, particularly in cases where the truth was not that obvious. His disciples as politicians, orators, lawyers, teachers in schools etc. had to learn how to write and hold speeches on all possible subjects and to get along in all social situations. Introduction of drawing and painting in the art education after Aristotle's advice was something new. Pupils mostly learnt how to draw human figure with charcoal. It seems it was not technical drawing but art of portrayal Man is the measure of all things. Therefore man was in the center of Greek thought.

Isocrates reduced judicial and political life to system which became dominant in Athens. All or almost all ancient culture will be inspired on this orator's ideal of eloquent and good speech. His program was much more modest than the Plato's but it was more practical and affordable which proved crucial for all later history of education. Plato's program was too complex and difficult in hardly achievable hope of reaching theoretical ,perfect science“" and it lasted infinitely which is why it had no relation with practical life.

\subsection{Seven „Liberal Arts“ as a Basis of Ancient Schooling}

School program in Athens was not set but it varied from one teacher to another, from one school to another. Number of arts and sciences learnt in these schools gradually came to number seven: grammar, logic, rhetoric, arithmetic, geometry, astronomy and music. These were „seven liberal arts“ (septem artes liberales). They were given this name as they were considered „worthy of a free man" as opposed to 
„mechanical“ or „slave“ (,unfree“) activities performed by unfree, unnoble men or slaves.

Within seven liberal arts we can easily distinguish two different groups or more precisely two stages - „literary“ or lower, called „trivium“ in which basic literary education in grammar, rhetorics and logic was obtained. The other, higher or „scientific" stage which was later called „quadrivium“ encompassed four numeral arts: arithmetics, geometry, astronomy and music (theory). Each of these disciplines introduced disciples into understanding of some individual or ,small secret" of nature and society and they were all together considered as means for getting to know ,the great secret" or philosophy in the strict sense of the word as ,true wisdom". Arts were in other words considered as propaedeutics, basis or general cultural preparation for the study of philosophy which was considered as a synthesis of complete knowledge, an ideal to which all efforts of the human thought should aspire.

Original core of seven liberal arts is ascribed to the Greek scholar and philosopher Archytas from Taranto who was born around 440 BC. As an exceptionally intelligent and educated man he studied mathematics, astronomy, music, moral issues and politics. In time other scholars and philosophers introduced other disciplines into use. In that way probably Gorgias from Leontini introduced rhetorics, Aristotle dialectics and Dionysius of Thrace (ca. 100 - ca. 30) grammar. He wrote a work entitled Grammatica (Grammar) after which he was called „Grammarian". They were given final form by the Roman philosopher Martianus Capella (Martianus Minneus Felix Capella) in the first half of the 5th century. His main work De nuptiis Mercurii et Filologiae (On the Marriage of Philology and Mercury) written around 420 was composed as a novel in which he offered systematic overview of all scientific disciplines of his time as the first of classical authors. He intended to present these arts to the readers in the most acceptable way in order to save them from neglect or oblivion. Therefore he wrote an allegoric story in the introduction of his work in which he combined prose and poetry presenting each of seven arts as servants of Mercury's fiancée called Philology.

These arts were basis of school lessons not only in ancient Greece but also in entire mentioned period, and later on. Their number was for a long time reduced to number seven although often there were more. As the time passed and knowledge grew, their number increased and was enriched with new insights so that it is difficult to determine with certainty how many disciplines were studies and considered as a part of school education. Scientific disciplines expand with process of science progress which is neverending.

Title of „free“ and „unfree“ i.e. „slavish“ arts may be surprising. Greek world was an urban world which had quite specific attitude towards manual work. Its ideals were seen in ,noble“ skills: war, politics, philosophy, literature etc, without paying attention to practical skills or works performed manually such as crafts, agriculture, fishing, shipbuilding or even architecture in perfect forms, painting, outstanding sculptures or famous pottery with painted vases in astonishing forms and elegance. Although these artistic works of eternal beauty evoke undivided admiration, none of these artistic or technical arts and sciences were included in the school program. These activities were performed by lower classes, artisans or gifted individuals whose work was appreciated, but it never led to foundation of some technical academy or 
school of applied arts. Plato (as most of the Greek philosophers) believed that idleness was crucial for obtaining wisdom which cannot be found in the individuals who have to earn their daily bread, but only in those financially independent or provided for by the state. Most of Plato's dialogues takes place in Pericles' time offering a pleasant image of life of the rich class. Plato belonged to an aristocratic Athenian family, and he grew in tradition of a period that preceded the time when war and democracy destroyed the wealth and safety of upper classes. His young men as aristocrats who did not need to work spent most of their free time dealing with science, mathematics and philosophy; they could recite Homer almost by heart and evaluate critically skills of the professional reciters. Aristotle's standpoint was similar. He never glorified work, nor did he recommend it as a way of attaining fortune. Purpose of work was to find free time. Physical works were performed by slaves and artisans (masons, carpenters, weavers, drapers, shavers, fishermen, merchants etc.) who learnt their crafts from their fathers. Since they performed them with traditional methods Greeks did not try to facilitate human work with invention of machines or use of energy for their starting. It was negative attitude towards work which was accepted by the Romans without resistance so that ancient world neglected the field of technology and mechanical inventions, with the exception of construction, in favor of works performed by ,free people“.

However the development of democracy and accordingly participation in public life of artisans, merchants, peasants etc. opposed to our expectations did not lead to better evaluation of physical work. Main representatives of cultural life were members of old aristocracy who continued to underestimate manual i.e. physical labor which deformed human body in their opinion, suppressed the spirit of generosity and subdued will. There were many Greeks who practised agriculture and craft but they contributed little to what was specific for the classical Greek culture.

This negative attitude towards physical work and „mechanical“ arts was accepted by the Greeks from other nations with slave-holding social system, primarily neighbouring Phoenicians; Tyre, Sidon and Carthage depended on slaves for physical works at home, and they hired mercenaries for leading wars outside the country not to be dependant on the numerous village population which had the same blood and same political rights.

\subsection{Schooling in the Period of Hellenism}

This magnificent ascent of the Athenian culture was violently stopped with envy and constant conflicts with Sparta. After the golden age in the 5th century and frequent wars with Sparta and its allies for hegemony over Greece, Athens was gradually but constantly weakened in political, economic and military terms so that it was never renewed as it was after the wars with the Persians. But it was still powerful in the fields of philosophy and science as well as school education particularly in Hellenism when Alexander the Great (356-323) led the Greek world to counterattack against the Persian Empire as their centennial enemy. In only ten years (334 - 324 BC) of war it was defeated by small but well organized army of the young Macedonian king. But Alexander was not only a conqueror but also a colonizer. He founded cities acrosss the conquered territories which usually had his name and which were ruled in the Greek way. Settled Greek and Macedonian colonizers 
quickly merged with local population. Alexander incited his compatriots to marry local women giving them personal example. It was a political expression to the expansion of Greek spirit which became particularly evident in the second half of the 4th century. Aristotle was a typical representative of this time of changes, and Alexander was his disciple. Alexander's greatness as in all great men was not only in his organizational geniality but also in the fact that he appeared on the historical stage at ,right time“. In the world which was preparing for him unconsciously, his spectacular conquest marked emergence of a new type of international community which later led to much stabler and lasting state embodied in the Roman Empire. In that way Greek civilization ruled the entire Mediterranean and Middle East, and great kingdoms replaced small independent cities-states which got municipal character instead of political. On the other hand this contributed to spreading of Greek influence to the entire known world, and Greek culture assumed universal characterisics. Greek was spoken from Gibraltar to Ganges. Science, philosophy and art had great impact on the old civilizations of the East just as these civilizations influenced mentality and science of their conquerors. A kind of osmosis of mutual influences started which was useful for both sides.

But this medal also had other side: with loss of independence of the Greek cities-states specific Greek spirit was lost leading to impoverishment of not only political thought and mutual individualistic competition of Greek states but also weakening of stimuli for daring intellectial speculations and comprehensive theories about reality and universe. Hearth of the Hellenistic culture, particularly science and technology was no longer on the Greek soil but in Egypt where Alexander of Macedon founded first and most important city with his name (Alexandria) in winter of 332/331 BC some $14 \mathrm{~km}$ west of the mouth of one backwaters of the Nile into the Mediterranean where the city of Rhakotis used to be. Alexander died in $323 \mathrm{BC}$ and his vast empire which spread from Egypt to India and borders of Pakistan did not outlive its founder for a long time. His generals divided the empire into several smaller but still powerful kingdoms after bloody wars.

Alexandria was particularly important when Alexander's general and heir Ptolemy I Soter $(305-284$ BC) made it a center of his state which encompassed Egypt, Cyrenaica, Palestine, southern Syria, Cyprus and some Aegean islands. It was a huge city, encircled with walls more then $18 \mathrm{~km}$ long, built after rules of Hellenistic city planning. Situated opposite the islet of Pharos, on approximately identical distances from Greece and Asia Minor, Alexandria soon became main merchant intermediate between the West and cultural centers of Babylon and Persia. Therefore Sostratus of Cnidus built a large lighthouse around 280 BC on the islet of Pharos in front of the port. The Greeks considered it one of the seven world wonders. It was about $135 \mathrm{~m}$ high, open flame at its top indicated way to the port to ships which could be at the distance of $50 \mathrm{~km}$. Alongside political and merchant importance of the city its cultural role also grew. Cultural influences from Greece, Egypt, Israel, Near East, Rome and other regions met and mixed here.

Following Alexander's Hellenistic ideas about multiculturality and wish to connect the Greek world with the East, Ptolemy I opened a Museum (Museion) in 290 BC in the complex of his court which encompassed one third of the city. Museum was a temple of muses and center of cultural, artistic and intellectual 
activity where emphasis was on research and patient collecting of facts. Museum was a kind of high school which could be compared to modern universities. All this attracted great number of experts and scientists from all fields: geometers, astronomers, physicians, historians, writers, grammarians etc. They all lived and worked in the Museum funded by the state. Royal officials took care of their material needs so they could concentrate on their scientific work. Within the Museum was the famous library, unrivaled in the ancient world. It contained research laboratories, astronomic observatory, classrooms, botanical and zoological garden and everything necessary for research work and intellectual activities in general. Owing to these advantages the Museum became a cultural center of not only Greek but also entire Hellenistic world, rival of Athens, Antiochia and Rome. Ptolemy I addressed all rulers of his time requesting to send him copies of all books and documents which they had in their archives. Well equipped scriptorium worked in the library. In that way many works of older writers were copied on papyrus and preserved, knowledge from the Mesopotamian archives was transferred, Egyptian and Jewish texts were translated. The library became the greatest, richest and most famous library of the Hellenistic period. At the end of Ptolemy's life it had almost 200000 volumes, and in the Roman period about 700 000. This unique and magnificent monument of ancient science and culture was damaged heavily in fire when the legions of Julius Caesar in 47 BC conquered the city. There were many famous scholars who worked in Alexandria. They lived in a luxurious palace with porches and gardens and were paid with state money. Their duty was to teach, research and write.

In the Hellenistic period schools were founded differing in program and stages. Program of ,junior grammar school“ consisted of a series of literary compositions after a plan from previous period which remained unchanged. Compositions were made after a strict scheme. No originality was welcomed, only correctness with regard to chosen pattern. Other disciplines were taught as well.

Geometry lectures consisted of a series of interrelated examples. Particular attention was paid to problem of construction on the basis of purely rational and theoretical plan. Practical application, calculating superficies and perimeter was taught later on.

The same was valid for arithmetics. Greek numeral system was very complex and difficult particularly when dealing with large numbers and it did not allow calculating with irrational numbers and fractions.

Theory of music was based on learning intervals and rhythms. Personal impression was important.

Astronomy was considered as an important subject but it was related with astrology. It was not taught from the manuals based on mathematics but on the basis of the epic poem „Phaenomena“" (Fainómena), by the Greek didactic poet and astronomer Aratus (ca. 310 - 245) written in 275 BC after the model of Plato's disciple, mathematician, astronomer and philosopher Eudoxus of Cnidus (ca. 409 ca. 356). This work had no numeral data and quite general technical data. Instead of that it was full of large descriptions of star ,figures” related with famous persons and mythology from which these persons originated. Epic poem was read at school not by some expert in astronomy but „grammaticós“ who offered purely literary 
interpretation. Nevertheless it was very popular in antiquity so that Cicero translated it into Latin in verses.

In other words more attention was paid to literature than to mathematics. Process of its depreciating continued. It was praised but it was never taught as a serious school subject.

Higher degree which could presently be called university degree started after becoming of age, with 18 years. It was divided in four directions: „ephebian”, rhetoric, philosophic and higher education or "scientific".

a) „Ephebian” stage was intended for the young men who became of age. It lasted for two years. An 18-year-old would spend the first year in the army barracks where he obtained physical and army education after taking an oath. On the second year they did practical military exercises, and ephebes (young men of age) were assigned to military frontier garrisons. After the Hellenistic period ephebia lost characteristics of an educational public-military institution and turned into a higher institution of physical education of not only Athenian aristocratic youth but also youth from entire Greece, Asia and later Rome. In time it turned into a separate study in which grammarians, philosophers and rhetors, sometimes and mathematicians held specialized lectures and conferences. We can state with certainty that ephebia existed in about hundred Hellenistic cities. In the 3rd century it disappeared as an institution.

b) Rhetoric direction consisted of theoretical part in which following aspects were taught: technique of including certain ideas in speech (inventio), way of presenting ideas (dispositio), advice for selection of the most suitable style in order to achieve certain effect (elocutio), manner of memorizing chosen texts necessary for success of the speech (mnemotechnica) and way of modulating voice and gestures. Practical part dealt with study of models (best speeches of classical orators) and composing disciple's own speeches after this model. Themes of speeches were usually related with political or private life, and sometimes they were purely fictional.

c) Philosophic or scientific direction mostly referred to the study of philosophy. Certain philosophical directions had their own schools organized as fraternities most famous being Platonic, Aristotle's, Stoic and Epicurean. There were also private teachers of philosophy, and travelling ones who travelled from one city to another to express their philosophies publicly at squares. Cynics were most famous. Some of these philosophical directions did not imply deep and complete education, and other demanded it as necessary prerequisite. Platonic direction demanded knowledge of mathematics. Then general terms of certain philosophical direction were taught, chosen texts were read and discussed. Finally teacher would present his own ideas at public meetings open to everyone or at lectures for school attendants. Philosophical lectures mostly encompassed logic, physics and ethics. In time ethics became the most important or even exclusive subject of lectures.

In this period there were no regular schools for professional training for a certain profession. Lawyers, engineers, sailors who played an important role in society obtained knowledge and practice with some older professionals.

The only difference was medicine which was an object of special interest from the 6th century to late Greek and Roman antiquity. Although its creation was related with the cult of the god Asclepius, it reached high level of rationalism and experimental study as early as the time of Hippocrates of Kos (ca. 460 - 377). 
Philosopher and physician Alcmaeon, disciple of Pythagoras (6th-5th centuries BC), Aristotle and some others did dissections. Fact that some of Greek state-cities in the 4th and 3rd centuries had well organized public health service in which physicians worked for free testifies to the fact that the Greeks were very progressive in this aspect. After Hippocrates medical school started to appear. Their achievements were presented and systematized by Aelius Galenus from Pergamon (129 - 200 AD), greatest medical expert of the Roman period whose theories had significant influence on western medicine for more than a thousand years. His description of medicinal anatomy was based on dissecting animals, and description of function of heart, arteries and veins was accepted until the 17th century when William Harvey (15781657) studied bloodstream more thoroughly concluding that heart was a pump and not center of emotions.

\subsection{Alexandria takes over Role of Athens}

One of the most respected scholars related with Alexandria was the mathematician Euclid $(330-275$ BC). He was a founder of the School of Mathematics in the Museum. He used a small number of axioms to write the capital work „Elements“, the oldest and most famous mathematical work which has been preserved. Since it is too systematic and perfect we can conclude it was systematization of works of previous mathematicians whose names we do not know. It consists of 15 books and it is one of the greatest monuments of Greek science. It contains planimetry, arithmetics, geometry and stereometry. It is a synthesis of all mathematical knowledge of ancient Greece until Euclid's time and one of the most influential works in history of mathematics which earned its creator the title „father of geometry". It was used as a main textbook for studying mathematics, particularly geometry. The Greeks exhibited particular affection for arithmetics and geometry. Since their view of the world was visual, their main scientific achievements were reflected in geometry. They viewed numbers as forms (therefore we speak of square and cubic numbers) so they solved arithmetic problems with geometric procedures. Some of them such as Euclid's Elements written about the year 300 BC are still a basis of initial teaching in modern schools.

One of the first head librarians of the library in Alexandria was the mathematician, travel writer, philologist and astronomer Eratosthenes of Cyrene (276 - 194 BC), author of numerous works from various scientific fields: geography, astronomy, mathematics, philosophy, literature and ethics. He is considered as the „father" of geography. He was famous for quite precise measuring of Earth's perimeter which differed from the actual one for only $80 \mathrm{~km}$. He proved that the Earth could be circumnavigated and made a map of the Earth on the basis of his ideas with seven meridians and parallels. He also determined almost precisely inclination of the ecliptic towards equator, length of a day and duration of a year.

Astronomer and mathematician Aristarchus of Samos (ca. 310 - ca. 250 BC) was the head librarian and educator of young Ptolemies. According to the present-day knowledge he was the first astronomer to promote heliocentric system after Heraklides of Pontus came to consclusion that the Earth rotates on its axis. His thesis was not supported by his contemporaries so we had to wait for Copernicus to prove it mathematically. On the basis of his observations he defined relative distances of the 
Moon and Sun from Earth. He explained fixed distibution of stars with their great distance.

Archimedes $(287-212$ BC) was probably the most famous mathematician, physician and constructor of antiquity. He was educated in Alexandria with Euclid where he became famous due to his scientific discoveries and soil improvement of the Nile swamps. After moving to Syracuse on Sicily he dealt with almost all questions related to mathematics and physics. He is considered as the founder of hydrostatics. According to tradition he had many inventions in the technical field: Archimedean screw, Archimedes' pulley, some military devices and spiral pump. $\mathrm{He}$ constructed a planetarium, defined a principle which was named after him („Any object, wholly or partially immersed in a fluid, is buoyed up by a force equal to the weight of the fluid displaced by the object."). He wrote many works such as On the Sphere and the Cylinder, On Conoids and Spheroids, On Floating Bodies, On the Equilibrium of Planes by which he promoted mathematical science more than anyone else in antiquity.

Alongside studying purely theoretical problems, natural phenomena and collecting theoretical information, in the period of Hellenism significant progress was made in production of mechanical devices and machines although they were rarely used to improve life conditions. These machines worked on the basis of sucking and spreading warm air. Alexandrian inventor and mathematician Ktesibios $(285-222)$ wrote discussions about compressed air and its use for suction-pipes and pumps by inventing hydraulic device which is considered as a predecessor of hydraulic organ. He described suction-pipes including firefighting machines which created stream of water or lifted water from a well. He is known as father of pneumatics. His invention was also clepsydra - a water clock which was used until the 17 th century when a Dutch mathematician, astronomer and physicist Christian Huygens (1629-1695) constructed mechanical clock with a pendulum. Another mathematician and engineer from Alexandria, Heron from the 1st century AD descibed a device working on the principle of jet propulsion. Many other inventions are ascribed to him, including „Heron's fountain“. He wrote treaties from the fields of mathematics and mechanics, and he also contributed to the development of science on heat.

Claudius Ptolemy (ca. 85 - ca.165) was a physician, astronomer, geographer and musician who worked in Alexandria between the years 140 and 160. He is the author of several important works. In his work Mathematical Treatise known as Almagest (after the Arabic translation in which it was preserved) he systematically presented his vision of the universe as a geocentric system. Although his view was based on the incorrect hypothesis that the Sun, planets and stars rotate around the Earth as a fixed center of the universe, his interpretation was in accordance with observing the orbits of planets so that it was maintained until the 16th century. $\mathrm{He}$ improved mathematical theory of movement of the Moon, Sun and planets, he derived theory of sun eclipses and presented new geometric proofs and theorems. His contribution to geographical science and cartographic understanding of ancient world is particularly great. He calculated the size of the Earth and described its surface. $\mathrm{He}$ used longitude and latitude for locating certain points. 


\subsection{Characteristics of Greek Humanism}

The Greeks possessed impressive practical knowledge from various scientific disciplines particularly mathematics, they could build magnificent temples, fortified cities and objects like the Alexandrian lighthouse, fast and powerful ships with several rows of oars which were unrivaled in te Mediterranean. In art, particularly sculpture and pottery they reached the peak which demanded knowledge of perfect technique. Despite all these facts they paid little attention to technics or mechanics and never came to idea to include into school program disciplines and arts such as architecture, sculpture, painting, shipbuilding, navigation, geodesy etc. which may have been very useful. There are many reasons for this paradox. Some of hem have already been mentioned. It seems that roots of such standpoint were in too strong authority of two scholars and philosophers: Pythagoras and Plato. Their interest in science and study of nature was motivated more with pure love for theoretical truth and beauty than with wish for its practical application. Isocrates supported the same mentality when he put emphasis of his educational system on humanistic subjects, and much less on mathematics. Their philosophers gave humanistic mark to the entire Greek culture. From that period educated man was not a builder of magnificent temples or a sculptor who carved sculptures with a chisel and hammer giving them the spirit of eternal beauty, but the one who learnt Iliad and Oddysey by heart identifying himself with their heroes or telling invented stories about love affairs of the Greek gods.

The Greeks could not learn technical arts at school but only with some private teacher or from their own experiences. We must not forget that there were few prominent individuals who promoted technical arts which enabled progress that humanity owes to this heroic period of history. Let us only remember Archimedes and his machines and mirrors that he made in Syracuse according to a legend with which he could burn enemy's ships at a considerable distance according to a legend. Their knowledge of technology is best illustrated by a shipwreck from the 1st century $\mathrm{BC}$ in which an outstanding instrument was found testifying to exceptional development of their science and technology: one axis moved more than twenty small wheels and cogwheels which indicated with needles position of the Sun, Moon and planets which testifies to outstanding technical-scientific achievements at the time.

However the fact is that magnificent classical Greek civilization to which the world owes so much was more humanistic in its essence i.e. aesthetic, artistic and literary than technical i.e. scientific. Historian Xenophon (430/425-355) realized that technical arts in the Greek cities were not only poorly appreciated but even despised in some communities. Various factors contributed to this so that and even the most distinguished scholars such as Aristotle. Although he was one of the greatest scholars of his time, excellent expert in biology and zoology who even made experiments and dissected animals in order to see how organisms function expressing impressive broadness of his genius, in one field he was not at the expected level. He believed his colleague at the Plato's Academy mathematician and astronomer Eudoxus of Cnidus (408-355) who developed theory of concentric planetary spheres with various direction of movements of planets among which Earth took the central position. This system was finalized by the previously mentioned Claudius Ptolemy making an 
incorrect conclusion about geocentric system. Evidently not even the best experts are immune to mistakes!

Essence of classical Greek humanism consisted of raising educated and responsible member of the community; man and not technician in moder sense of the word; man who is free, rich and educated; aristocrat with refined taste; man who was left to his own devices by fate and gods so that he attempts to grasp something certain in his life as opposed to a world without borders and under the empty sky; man who relies on himself in this mysterious and uncertain world.

Ideal of Greek humanism was formulated by the sophist Protagoras from Abdera (491/481- 411 BC) who is called the „teacher of virtues“ by Plato: „Man is the measure of all things: of things which are, that they are, and of things which are not, that they are not". What is not suitable for a man cannot be truthful. Man must not take things for granted but he has to doubt and question everything, explore in order to obtain most complete comprehension of the world around him. Alongside culture of spirit he has to nurture culture of the body which implies exercising certain sports. These two components of the human being had to be in balance of intellectual i.e. spiritual capacities and physical abilities: ,a healthy mind in a healthy body“. Final aim of this ideal was upbringing of a complete human character, constant discovering of what is considered the greatest good for a man, what can give sense and value to a human life and what most people appreciate most. These aspirations make a man want knowledge, make him search for the truth. Truth, beauty and moral kindness are greatest human virtues. It was what the Greeks wanted to achieve and their philosophers helped them in finding answers. „Discovery of a man“ was one of their greatest discoveries. They were never bothered with material side of life particularly with what we call economy which was something related to good managing of family economy for them and other philosophers until the 18th century. Although they did not refrain from wealth they did not run after it. Therefore they raised their eyebrows at chasing wealth for wealth.

\subsection{Rome as a Military Master and Cultural Disciple of Greece}

In the period when Sparta, Athens and other Greek cities-states were in zenith of their political power and cultural ascent, Rome was a rural settlement which gradually grew on moderately steep slopes of the Palatine hill in central Latium without any indications that it may become not only ruler of the Apennine Peninsula but of the entire known world. Its transformation into a city and spectacular expansion was the result of exceptional military organization and politically genial idea of including defeated populations into their state. One of the secrets of their success was raising forts (colonies) in conquered regions in which they settled their citizens. After they became masters of the Apennine Peninsula three wars with the Carthaginians followed (in the 3rd and 2nd centuries BC) in which they conquered not only Carthage but also the entire Mediterranean and Near East coming in that way in contact with many nations and cultures including the Greeks to which they gave much and from which they learnt much.

As opposed to the Greeks as pronounced individuals and people prefering speculative thinking, the Romans were too inclined to sacrifice individuality for the sake of collectiveness and they were much more practical in their lives. This opposite 
does not come out only from different characters but also from different roads these nations underwent in their development. What is usually called „Roman virtue“ is nothing else but old ethics of a city whose inhabitants believed in strength of unity. Rome always cherished ideal of unitary state to which interests of the citizens must be subjected. Rome never renounced this ideal even in the period of highest state ascent when there were no outer dangers. It is sufficient to remeber Augustus' efforts to restitute old moral when Horace after the model of the old Spartans said: „It is sweet and right to die for one's homeland."

Roman upbinging was based on values of rural society and not ideals of Greek knightly upbringing. At the end of the 6th century Roman culture was a culture of rural aristocracy, culture of rich land-owners occupied with agriculture, society different from Homer's warrior aristocracy.

A young Roman was first raised in his family where mother played an important role. At the age of 7 father took over upbringing until boy's 16th birthday when he put aside a toga lined with purple and dressed white toga of an adult. Some dignified friend of the family was entrusted with his education at that period who taught him things from public life for a year. Then he went to the army following directions of some mature politician as a regular soldier and was subjected to strict military discipline. Young soldier had to learn how to use all kinds of weapons, how to fight with weapons and bare hands (boxing and martial arts), to adjust to all hardships of his profession, to endure most demanding physical efforts, be able to swim in a fast and cold river in harsh winter conditions and all other skills that may be useful in cruel military life. As opposed to the Greeks, Romans did not exercise sports. They practiced various games in order strengthen their muscles and improve physical resilience. Instead of sport competitions Roman soldier went to circus and amphitheater where he practiced riding and martial arts. Sons of peasants continued service as regular soldiers and noblemen's sons went to officers' class in which they could advance in career. Throughout all this time he was taught traditional Roman ethics which was supposed to last throughout his life, particularly love for homeland for which he had to be prepared to die.

In Rome upbringing was different from the Greek one at the beginning. But in time it developed in quite different direction. Rome was forced to accept forms and methods of Greek upbringing. This happened after conquest of Magna Graecia on the Apennine Peninsula, Punic wars and unstoppable spreading over the Mediterranean. The Romans were superior military power, but they were inferior culturally. After the victory over the Achaean League in 146 BC entire Balkanic Greece was joined with the province of Macedonia.

Conquest of Magna Graecia in southern Italy, and then Greece by Alexander's heirs after the victory over the Achaean League in $146 \mathrm{BC}$ and its annexation with the province of Macedonia was crucial in the later Roman and Greek history. It had surprising political and cultural consequences for the Greeks and Romans: military winners soon became cultural losers, and defeated Greeks (in military terms) became cultural winners over Rome. In that way they were both winners and losers at the same time. Understandably this situation had advantages and disadvantages for both. Many educated Greeks started to arrive to Rome as a consequence of occupation of Greece, mostly as slaves who transferred their centennial culture and knowledge to 
new masters and their children. E.g. Roman Empire in Augustus' period had about a million inhabitants in the city of Rome and in other parts of Italy about 13 million. At least 4 million of them were slaves. It is understandable that an ancient Roman as well as an average Greek did not sweat and practice physical work but he could be involved in war, politics and leisure. „God has given us this leisure“ (Virgil). There were the ones who condemned this fatal practice. „Leisure without intellectual work is death and grave of every living man (Seneca). But such wise men were not respected by the others. If the Roman spirit proved to be superior in comparison with the Greek spirit regarding war skills, state administration, building, law etc., in many other fields it was just the opposite. Soldiers, officers and magistrates quickly accepted customs of the conquered regions. Romans encountered Greek culture for the first time during the Second Punic War (218-202 BC) when in 211 BC general M. Claudius Marcellus brought many works of art from conquered Syracuse as war booty. These works aroused great interest of the Roman population. This proved to have greatest cultural importance for future. Sparkle of interest in art which was awakened then ensured survival of the Greek art after the subsequent Greek catastrophe. Furthermore it was nurtured in the Roman Empire so that it could influence later European culture. „During the Second Punic War muse joined wild warlike Romulus' genus.“ (Portius Licinius).

The Romans evidently possessed strong affinity for cultural values alongside their affinity for wars and conquests. This affinity is not immanent to distinctly warlike nations. Not only works of art started coming from conquered Greece in great quantities but also new ideas, feelings, aspirations embodied in Greek artists and educated men who were about to work in Rome and for Rome.

Interest in Greek culture grew in Rome particulary after the consul Lucius Aemilius Paulus from Pella, the capital of the Macedonian kingdom transferred the library of the Macedonian monarchs in 168 BC. General Lucius Cornelius Sulla (13878) confiscated Aristotle's library and moved it to Rome and Lucius Licinius Lucullus brought equally important Mithridates' library from Pontus in 71. It is believed that over 25 libraries existed in the city in the first two centuries of the Empire. Lively trade with books developed, and rich collectors searched rare specimens of certain works to put them in their often luxurious libraries. Books for sale were made in a way that a text was dictated to a large number of slaves. Only in the mid-1st century AD leaves of parchment were used as predecessors of presentday books. In that way something unimaginable happpened: Greece which was conquered military, conquered Rome culturally. Educated Romans were aware of that. „Conquered Greece conquered wild winner and introduced art into rural Latium" (Horace).

This ,flood“ of cultural wealth and educated people gave a strong stimulus for the Romans to develop their own talents in various fields which enabled their civilization to start turning from military civilization to the one of high culture in all fields. In that way cultural „colonization“ of Rome started.

But Romans proved to be not only excellent soldiers but also good pupils. As bright and pragmatic people they learnt quickly from their Greek teachers. Their conquest of Greece was a strong stimulus for developing their own talents in various fields which enabled their civilization to start transforming from a warriors' 
civilization to the one of high culture in almost all fields. In that way cultural „colonization“ of Rome started. Learning Greek language became quite common. Rich Roman families were willing to pay for lessons in Greek for their children. It was difficult to find a dignified Roman aristocrat who did not speak Greek. Greek became „lingua franca“ among various nations i.e. diplomatic language, but also the language of Roman enemies who were about to become their eastern subjects.

However it would be incorrect to say that the Romans only took material things from the Greeks. They were able to develop, transform and improve many things which is particularly evident in art and architecture. On the Athenian Acropolis in the 5th century BC the Greeks said everything there was about architecture: in Doric Parthenon, Ionic Erechtheion and Doric and Ionic Propylaea. However even if this is undoubtedly matchless master-piece of classical Greek architecture whose outer side is decorated with a series of heroic immaculately carved figures, art historians cannot agree as to extent of particular inner life of the object and its decorations and intensity of emotions transferred on the observer which may be expected from such a work.

The Romans as opposed to the Greeks paid much more attention to importance of interior design of their temples which was in accordance with their understanding of religious art and relation with the individual as a person. New building technique was particularly helpful in that, use of arch which they took from the Etruscans and building material (marble, brick and a kind of concrete which was made from lime, volcanic ash, sand and brick) which revolutionized their architecture so that in the period of the emperor Augustus their construction blossomed. This is evident from solid and well arranged cities with rational plan and well projected drainage system, spatious and beautiful squares, triumphal arches, temples, basilicae, conference halls, theatres, public baths, roads, bridges, palaces, houses, multistoried water supply systems which brought water to the cities from large distances etc. Their builders had to find solution which surpassed everything known until that point. Their miraculous objects belong to greatest architectural achievements of humanity with their size, solidity and beauty.

Main promoters of architecture were the emperors who gave new meaning and expression of personal aspirations to architecture: to show and represent the strength of the Empire. The oldest preserved large monument is Pantheon which was built between 27 and 25 BC by general and Augustus' friend Marcus Vipsanius Agrippa and it was reconstructed by Hadrian (120-124). It was conceived as an interior dedicated to planetary deities. It has massive walls supported with huge marble columns which taper towards the top carrying a magnificent dome whose height is equal to diameter $(43,30 \mathrm{~m})$ with a $9 \mathrm{~m}$ wide round opening at the top. It is the most impressive object from antiquity which was preserved and it belongs to the most magnificent master-pieces of human spirit.

Before the end of the 1st century, more precisely in the year 72 Emperor Vespasian started building Colosseum, oval arena with three rows of arches, fourth upper storey and vertical rows of Doric, Ionic and Corinthian columns of the largest extant object of the imperial Rome with impressive dimensions: 157 x 188 m which could accommodate over 45.000 spectators. Roman builders had to overcome a series of structural problems of such huge building. Five centuries after Parthenon 
architecture saw its inner and outer transformation: exterior became interior i.e. outer side became inner.

Human spirit underwent similar transformation. Art, politics, philosophy and religion changed image of a man and outer world which was no longer sum of unrelated phenomena with many scattered and fighting cities-states. It became an organically related whole with well arranged and efficient state administration at whose head was the emperor with unlimited power. Symbol of the new world was Pantheon which represents Rome in art as Parthenon represented Greece. „My intention was that this sanctuary of all gods should be image of the Earth and heaven on which seeds of eternal flame stand containing everything“, said Hadrian about his Pantheon.

What is perhaps most interesting in this spectacular development is the fact that all this development would be impossible without understanding higher mathematics. There were no mathematical schools or interest in mathematics in Rome. Romans were aware of this. Learned Cicero wrote: „Mathematics was esteemed most highly by the Greeks and therefore no-one was more famous than the mathematicians. But we have limited use of this art to calculating and measuring." This measuring also referred to time. The Romans made a very precise calendar which remained in use essentially until present day (Julian calendar), they determined duration of months, division of the day to two parts, etc.

Development of Latin language represents a special chapter in the Roman history. Parallelly with learning Greek Romans perfected their language. Latin writers perfected their language of peasants and soldiers and made it suitable for expressing the most complex literary or philosophical thought easily and logically. There were excellent satirists, comedians and prosaists. Virgil looked up to Homer, Seneca to Euripides, Plautus and Terrencius to Menander etc. It was similar in other fields: painting, sculpture, technique, architecture.

Perhaps the greatest contribution which conquered Greece gave to its political masters, and later to the entire west was belief in reason and importance of art, literature, science and schooling. This helped Latin culture to rise to unimaginable heights for „rural Latium“ and to reach artistic heights of universal value.

First schools in Rome started to appear in the 6th century BC under influence of conquered Etruscans which accepted it from the Greeks just like alphabet. But with spreading of the Roman state across the Mediterranean Greek influence strengthened at the expense of the Etruscan influence. While Roman aristocracy raised their children in Greek spirit making „learned Greeks“ of them it simutaneously accepted Greek schooling system in which identical or almost identical subjects were taught as once in Athens only in Latin.

In the mid-3rd century schools were founded in which Greek teachers taught Roman children about the Greek writers, particularly Homer. This would not be possible if Roman literature had not already existed. Roman patriotism would not allow such Greek influence without teaching Roman literature. First Greek professor of Latin literature in Rome was Livius Andronicus from Taranto (ca. 280-200) who translated Oddysey to Latin for the needs of his pupils and some other works of Greek classics. A hundred years later another Greek, Quintus Ennius (239-169) poet 
and dramaturgist considered as the „father of Latin literature“ introduced in program of these schools classical Latin writers.

School program of the Roman schools used established system of trivium and quadrivium: grammar, rhetorics, dialectics, arithmetics, geometry, astronomy and music which remained as a basis of school program throughout the Middle Ages. However school program was not set and unchangeable but it was altered and supplemented depending on the context and circumstances. Marcus Terentius Varro (116-27 BC) who was educated in Greece from 84 to $82 \mathrm{BC}$ as many other Roman young men attending the lectures of the academician Philo of Larissa and Antiochus from Gaza, is the author of more than 70 works of various contents. He learned several scientific disciplines: grammar, history, geography, law, rhetorics, philosophy, astronomy, pedagogy, medicine and architecture. He wrote work De lingua latina (Latin language), the oldest grammar in Latin, in which he paid special attention to the study of language in two phases: studying poets, historians and orators and their works (ars disserendi) and eloquence (ars loquendi). The aim of this cognition was mathematics, music and astrology, while medicine and architecture belonged to practical knowledge

Marcus Vitruvius Pollio (ca. 80-79 BC - ca.15 AD) writer, architect and engineer went one step further. He became famous particularly owing to the work „De architectura" (On architecture) in ten volumes written in $23 \mathrm{BC}$ and dedicated to the Emperor Augustus who promoted complete renewal of Rome after the civil war. This work is the only and as such most important complete text on architecture from antiquity. It had immense influence on all later western architecture in technical and architectural terms. His aim was to educate able architects. Presently we cannot know if he was successful in his intentions.

As opposed to Vitruvius Marcus Tulis Cicero(106-43) insisted on learning oratory. In the period when education and public life were impregnated with oratory learned from Greek teachers, he believed that an orator was most apt to teach and discuss public problems. However in order to speak publicly he haf to master complex technique of this art, and be broadly educated and full of virtues. This was particularly valid for politicians and lawyers which had to know well subject they were discussing. Need to satisfy both demands made Cicero claim that eloquent man can learn fast and well anything even better than professional orators. Therefore it is necessary that an orator makes an additional effort and obtain general culture in addition to the one provided by seven liberal arts. He had to know law, philosophy, dialectics and manners, history, belles-lettres etc. In brief he had to obtain erudition characteristic of an educated man. This flexible understanding of liberal arts and education which could easily be changed and adapted to various needs will become main characteristic of western European culture of the Middle Ages.

Whatever Cicero asked from others, he realized it himself. Owing to oratorical talent and thorough education he mastered all skills which is why he could speak very convincingly in the Senate, courtrooms, public assemblies etc. He could speak with the finest words and use most convincing arguments with which he laid foundations of later oratory and oratorical prose. On the basis of his preserved speeches it is clear why he was considered as the greatest orator in history alongside Demosthenes. 
Although rhetorics in Roman schools was at a high level, quality of classes reached level of Greek schools only in Augustus' period. Around 26 BC Q. Cecilius Epirotes introduced in schools commenting important Latin poets such as Publius Vergilius Maro (70-19), Horatius Flaccus (65-8) and some others. From that time school system did not change much. An educated Roman who knew Virgil was estemeed just as some Greek who knew Homer.

In Rome as well is in regions with dominant Greek influence there was threestage school system with corresponding three types of schools. We could call them conditionally elementary and high schools and higher education institutions.

First-stage (,elementary“) schools were managed by teachers called litteratores, primi magistri, magistri scholae, magistri ludi, magistri ludi litterarii and padogogi. They were attended by boys and girls at the age from 7 to 12. Pupils mostly learnt how to read and learn by heart shorter texts, only to practice memorizing. Calculating was also taught with emphasis on operations of multiplication, division and fractions. Teacher (magister ludi) neither knew nor taught other operations. This was taught by another teacher (calculator). Lectures were usually held in open space where pupils were sheltered by a special veil (velum) from the street noise and curious looks or in some room near the square gathered around teacher who sat at the table (,cathedra"). They usually sat on chairs holding in their arms wax tables (tabulae cerate) leaning on their knees.

Second stage (,high“) schools were managed by lecturers called grammatici. Mostly boys from the age of 11 or 12 to 15 or 16 from wealthy families attended them. Main subject was learning Latin grammar by heart and chosen texts of classical writers (Virgil, Horace, Terrencius, etc.) as a practical exercise of style and everything that an orator had to know. Prose writers, historians (G. Iulius Caesar, Tacitus, Livius, Salustius, etc.) were rarely taught at this stage. Cicero represented matchless ideal of oratorical art as he embodied, as Virgil, almost entire Latin culture. Roman pedagogy in that sense immitated Hellenistic model.

In brief in Roman schools humanistic and theoretical subjects were favored. Although Cicero and Isocrates often emphasized importance of mathematics in their programs, teachers often neglected this instruction. Quintilian who was at the Plato's level emphasized that ,there is no orator without geometry“ in vain. His appeal was listened to, but it was not executed in practice. Mathematics in Rome remained at the stage of practical, rudimentary arithmetics and elementary geometry which could be used in geodesy and architecture. This was the reason why Romans did not leave important trace in mathematics except several mediocre compilations.

Third-stage (,higher") schools took significantly higher place than two lower stages at the scale of professional and social values. They were intended for education of young men who wanted to pursue political career or prepare for lawyer's profession which was highly esteemed and in demand.

Young men continued to attend school until they were 20, sometimes even longer, after they dressed „manly“ toga at the age of 15 or 16. In this school they learned subjects which were necessary in public life: knowing justice, laws, customs, various subjects related with questions of state policy and above all rhetorics as art which implied knowledge of Latin classics as means of mastering art of eloquent and correct speech. Rhetors (rhetores) or orators (oratores) held lectures in rhetorics. 
They took care that all attendants of this stage practice composing speeches about some theme or subject which demanded good knowledge of oratorical skill as was the case in Greece. This demanded good memory, lively imagination, solid philosophical education, psychology, law, history etc. Practical exercises were performed publicly with participation of schoolmates, friends, family, and citizens. Candidate had to show that he can vividly represent a socially important problem and convince listeners into a way of its solution.

Particular attention was paid to Roman law which was an original Roman invention. Its foundations were laid in the 5th century BC with the Law of the Twelve Tables (Leges duodecim tabularum). Basic determinants of the Roman law were based largely on universal ethical values and terms of universal law of the ancient world. It reached its peak of development at the end of Republican and beginning of Imperial period mostly owing to activities of Roman lawyers who developed private Roman law based on principles of freedom of private property, freedom of making contracts and freedom of disposition by will. Their legal reasoning was characterized by precision, clarity, exactness and consistency in finding just solutions for each specific case. Experienced lawyers (magistri iuris) taught law at schools. Mere knowledge of laws was not enough but there also had to be developed sense and care for greater good and justice. The Romans were aware of that as the greatest good to which young generations should aspire which opened doors of high state positions. Best manual for learning all this was lost Cicero's work De iure civili in septem redigendo in the best manner of Greek logic and Roman law. Other unavoidable manual was Institutiones which was made between 168 and 180 by the lawyer Gaius. Exceptionality of this manual refers to the fact that it was only work of classical Roman law which was preserved unaltered. There were also methodically composed law collections or Digesta. This legal activity reached its peak at the end of the 2nd and beginning of the 3rd centuries with lawyers such as Eneus Domitius Ulpianus (ca. 170-228), Aemilius Paulus Papinianus (177-213) and Iulius Paulus who left behind them classical works which will be model for all later lawyers.

In the early Christian period of the Roman Empire law study lasted for four years and the fifth year was introduced dedicated to the study of imperial decrees which were collected in a special code (codex). There were other codes: Codex Gregorianus and Codex Hermagonianus which were formed owing to private initiative. Only Emperor Theodosius II proclaimed official Codex in 439. Development of the Roman law was finished by the Emperor Justinian with his codification (528-534) called Corpus iuris civilis with which Roman legal sources were systematically arranged and legally stregthened. Most famous law schools were in Beirut and Constantinople where law was studied and taught at the highest level. There were many other law schools across the vast Roman Empire which preserved Roman law tradition of exceptional universal importance for future generations.

In brief no matter how strong Greek influence on the Romans was, it did not significantly change nature and purpose of the Roman education which was more practical than Greek, but not technological. The Romans also supported the belief that they should not make their hands dirty by a certain craft or manual work just like the Greeks did. Much greater number of the Romans than Greeks could count on constant influx of slaves who would do all manual labour. 


\subsection{Lights and Shadows of the Roman Civilization}

School program of the Roman schools was gradually reduced in late antiquity. Rome turned away from Greece more and more and the Romans learnt Greek language less so that great cultural and scientific heritage of the Hellenistic world was reduced to telling certain interesting anecdotes preserved by certain writers, particularly in Naturalis historia (Natural history) in 37 books by Pliny the Elder (23 - 79) and his imitators. Pliny collected from the Greek works several thousands of references, statements and weird legends, peculiar medical recipes which circulated in the Middle Ages. In that way the number of disciplines was reduced, together with former knowledge. But in them priority was given not to humanistic sciences but to certain technical sciences and disciplines: agronomy, geometry, civil and military architecture etc.

\section{Humanistic and Technical Education in the Middle Ages}

\section{1 „Unhistorical Nations“ erase Traces of Ancient Culture}

Greek, Hellenistic and Roman culture in the region of the Western Roman Empire received heavy blow during the Great Migration period from the 5th to 8th centuries. In the turmoil of raids of new ,unhistorical“ nations torch of Greco-Roman culture and science was almost extinguished. Schools disappeared together with the organized state administration. New Europe which was born gradually in „labor" of these processes had no connection with former Greco-Roman culture. Its renewal had to start from the beginning. In order to make any progress it was necessary to start digging up the ruins and to rediscover ancient writers together with the methods which enabled that their works might become part of the school program. It took a lot of effort, knowledge and good will, and final outcome was uncertain. The Middle Ages was formed gradually and modelled owing mostly to three important factors: Christian religion, revived Greco-Roman culture and renewal of the Roman Empire under the Germanic control.

Medieval West started to rise from the ruins of Greco-Roman world starting from the 8th and 9th centuries owing mostly to the Catholic Church which knew how to establish constructive relations with new masters of the European continent. Although its education was not primarily of the school-type, this by no means meant that the Church was not interested in it. Church needed not only literate but also educated men in order to exist and to expand. Christianity was ,religion of learning“ or „religion of book“" which could not exist in a completely barbaric context. That is why the Church had something to offer to the Germani. Church did not approach them with empty hands, but it brought them, alongside faith, Greco-Roman culture enriched with the Christian religion and contributions of many philosophers and theologists, including prominent representatives of all important philosophic schools, particulary Platonism, Aristotelianism, Stoicism. Their task was to save as much as possible of the Greco-Roman culture in Christian guise. They introduced new liveliness into the Christian message by their cultural creativity and opened up new horizons, laying in that way foundations for the new age. Historical development of schools and their programs led to their improvement and unification despite all differences from one author to another and from one period to another which finally 
led to founding universities which grew into well organized and institutionalized institutions some of which still exist.

\subsection{New Masters of Europe and Catholic Church}

Introduction of the Christian era afer the fall of the Western Roman Empire was a symbol and hallmark of the new age. Particular contribution to this period was made by a Scythian monk Dionysius the Little (Dionysius Exiguus, $\uparrow$ 556) who was the most renown lawyer who lived in Rome in his time. In his work Liber de paschate (Book on Easter) he supplemented Easter tables of Cyril of Alexandria after the Pope's order in 525. Instead of Diocletain's era which started with the beginning of his reign (September 17, 284), Dionysius decided to determine the exact date of Christ's birth. He took the period of M. Terentius Varro as a starting point in his calculations, and determined that Jesus Christ was born on December 25, 754 after the foundation of Rome ( $a b$ urbe condita) which was accepted as the beginning of the Christian era (ab Incarnatione Domine). New system of year numbering started as a sign of new age in history of Europe and world.

At the beginning Christianity did not accept ancient pagan philosophy but it accepted ancient educational system, intellectual technique of Greek Aristotelianism. However church fathers accepted and adjusted system of seven free arts retaining Latin as the language of culture and science. Therefore Christianity took over ancient heritage giving particular importance to some authorities of paganity such as Plato in neoplatonistic form, and a part of Aristotle, Cicero and Quintilian which had a place of honor together with the Christian authorities: Bible and church fathers. Christianity also accepted late antique thought regardless of the fact that it was not on high level. It was incorporated into their cultural and pedagogic program made by church fathers and monastic thinkers therein lying foundations for the Christian philosophical thought.

These attempts were rewarded. Special merits for that go to four Christian intellectuals of this or somewhat later time which are considered as ,the founders of the Middle Ages" after the Germani had already controlled largest part of what used to be the Western Roman Empire. These were Boethius, Cassiodorus, Isidore of Seville and Venerable Bede. All of them lived in the transitional period between antiquity in whose schools they were educated and the new age which only started to emerge in labor of the Great Migration period. They attempted to collect all scientific information which were still available in the disappearing world, or had already disappeared, to confirm their importance and give them an opportunity to blossom again in the schools. In that sense they determined basic cultural direction of that heritage which will be continued by almost all later Christian thinkers in the Middle Ages.

\subsection{Unsuccessful Attemp of Symbiosis of the Germani and Romans: Boethius}

The first one was Boethius (Anicius Manlius Torquatus Severinus Boëtius, ca. 480 - 526) the last descendant of the Roman aristocratic Anicia family. He was born in the period when Odoacer's Visigothic kingdom was in difficult position due to raids of Theodoric's Osthrogots. He was raised by the senator Aurelius Memmius Symmachus as his father died while he was young. He married his foster-father's 
daughter Rusticiana. He entered politics early becoming a senator at the age of 25 and only five years later a consul. Owing to Ostrogothic king Theodoric the Great, two of his sons were also appointed as consuls in 522. While performing state offices he found time to perfect his knowledge of Greek language and philosophy. His intention was to translate to Latin works of important Greek philosophers, primarily Plato and Aristotle, to make legacy of the ancient Greeks available to the Latin youth and to prove that differences between Plato and Aristotle are almost non-existing. He came to this idea considering division and increasing political and cultural distance between Rome and Constantinople, East and West. In this engagement with school education, Boethius was already a typical medieval man.

Although Boethius did not manage to realize fully his grand plan, he left an outstanding legacy behind. Later generations can thank him for the allegoric image of philosophy which can still be seen on fronts of some medieval cathedrals as well as for the definition of science. In his opinion philosophy is love for wisdom. This refers not only to practical ability, nor abstract speculative ability but reality. Wisdom is a living thought, cause of all things which exists in itself and by itself. After enlightening man's thought, wisdom attracts it with love. Philosophy can be understood as an achievement of wisdom, quest for God or even love for God.

Boethius introduced the term quadrivium which encompasses all higher disciplines. This a group of four disciplines related to the study of nature: arithmetic, geometry, astronomy and music. Meaning which he ascribes to the expression quadrivium is „quadruple path to wisdom“. These sciences are some kind of paths leading to wisdom. Who does not know them, cannot appreciate wisdom.

Boethius was the author of a series of didactic works on arithmetics (De institutione arithmetica). Ars geometrica is also ascribed to him. This work is different from the mentioned work on geometry which illustrates popularity of mathematics with the Romans. It remained unavoidable textbook for attendants of the quadrivium as higher educational stage.

Boethius is the author of other important works. One of them, which was later lost, dealt with anatomy, as well as the tractate De institutione musica (Music treatise) in five volumes. In it he discusses the problem of acoustics and elementary theory about tetrachords. His work was the main source of information about ancient music theory for the musicians from the Middle Ages and Renaissance. These works are important because they preserved ancient scientific legacy which provided great reputation for Boethius in medieval schools.

\subsection{First Signs of Recovery: Cassiodorus}

His disciple Cassiodorus (Flavius Magnus Aurelius Cassiodorus, 485 - 583), son of a famous praetorian prefect (praefectus praetorii) followed Boethius' way. After exclusively Latin education which was based on grammar, law and rhetoric, he began serving in the administration of the Ostrogothic king Theodoricus very young becoming a consul (consul ordinarius) in 514, then praefectus praetorii, in 533 patritius and finally „the first minister“ (magister officiorum). Four Osthrogothic kings named him their minister: Theodoric, Athalaric (526 - 534), Theodatus (534 536) and Vitiges (536 - 540). Cassiodorus was one of the most prominent Romans in his long political career who cooperated patiently with the Germanic kings in an 
attempt to pacify and unite Romans and Goths. He acted in a conciliatory tone in a political crisis which emerged between the Goths and Eastern Roman Empire. However the development of events did not correspond to his political ideals.

In an attempt to revive ancient culture, Cassiodorus founded high Catholic school (academy) in cooperation with the Pope Agapetus (535 - 536). Due to the Byzantine-Gothic war this school had to be closed. His great libaray was also destroyed. Faced with inevitable bloody conflict between the eastern Roman emperors and Goths, which marked the entire period, during the reign of Vitiges (540) he retreated to his estate in Calabria where he founded two monasteries one of which was the „Vivarium“ monastery where he tried to realize his ideal. His monastery soon became a true „temple of culture“ in which he tried to harmonize ancient culture with the Christian, with which he symbolically introduced classical culture into the "narrow cell of the Middle Ages“. Numerous Romans followed his example accepting the same lifestyle. Cassiodorus as a monk made a special monastic rule De institutione monastica, seemingly after the Rule of St. Benedict. One of the basic points of his rule referred to obligation of the study of sacred and profane sciences and copying old manuscripts. He knew that was not a period of great new thoughts and ideas, but that it was necessary to save from antiquity all that could be saved and that could be used in the society he lived in. He made no difference between the Greek, Latin, Christian and non-Christian authors. He believed that without knowing philosophy there can be no true theology. In that way his monastery became strong cultural center for the study of sacred (litterae divinae) and profane (litterae humanae) sciences. For his monks he made a manual of Latin orthography (De orthographia) and instructed them how to copy properly old manuscripts contributing in that way to preservation of old cultural heritage. It was an immensely important act for preserving ancient culture which was about to inspire numerous generations of the Christian monks. He was the embodiment of an educated monk who will have many followers in the future.

Cassiodorus and Boethius are considered as the ,founders of the Middle Ages“ and represent an important link in the chain of transferring knowledge and science between the late antiquity and Middle Ages.

\subsection{Renewal of Monastery Schooling: Isidore of Seville}

If culture in Italy which was devastated by the raids of new populations, perhaps more heavily than any other part of the former Roman Empire, could hardly survive closed in the monastery schools, in some other regions it continued to create important instruments which enabled continuation of some forms and traditions of knowledge to say the least. This primarily refers to relatively peaceful Visigothic rule in Hispania where strong church hierarchy was retained taking care of not only preservation but also development of ancient culture.

Among the church representatives who did not allow torch of ancient knowledge to be extinguished special place belongs to Isidore, archbishop of Seville (ca. $560-$ 636). Isidore's knowledge was encyclopaedic. He was acquainted with classical antiquity so he continued the work of Boethius and Cassiodorus. He is considered to be the last church Father and one of the most important writers of the time. He wrote about various subjects which may interest an educated man of his time, particularly 
about natural and humanistic arts and sciences. In the work Differentiarum libri he presented a comprehensive dictionary of synonyms and words. In De ordine creaturarum he wrote about cosmography, meteorology and other natural sciences. Originum seu etymologiarum libri XX made between the year 622 and 633 takes a special place among his numerous works. Isidore considered etymology part of grammar. „If you know the origin of a certain word you will easier understand its strength. Every word can be understood clearer if one knows its etymology." Since all things were not named after their nature, but some were named randomly, not all words can be reduced to etymology. The first three books of Isidore's encyclopaedia discuss seven liberal arts. In the others he presented not only origin of words or etymologies - as the title says - but also the complete profane and church knowledge in 20 books: I. Grammar; II. Rhetoric and dialectic; III. Arithmetic, geometry, astronomy, music, medicine, general history from the creation of the world to 627 $\mathrm{AD}$, Bible and church offices, God, angels and church members, Church, languages, nations, states, families, dictionary, man, animals, cosmography, geography, monuments and communication ways, science about stones and mineralogy; agriculture and gardening; army, war and games; navy and clothing; diet, household skills and agricultural implements. He particularly emphasized importance of arithmetics for proper understanding and interpretation of Biblical secrets. He explained comprehensively difference between astronomy and astrology, structure of the universe and definitions of Sun, Moon, planets, comets and fixed stars. For the Sun he states: it is made of fire, it is much larger than the Earth and Moon, except daily movement it has its own movement because of which it can be noticed at various positions in the universe; Moon takes its light from the Sun and goes through eclipse when it stands between the Sun and Earth; planets have their orbits; fixed stars also move which can be concluded from the change of their light depending on the distance from Earth; stars have various sizes: those closer to us and brighter can be much smaller than the ones less bright; strength of their light depends on their distance from Earth. Isidore's miscellany contains practically entire human knowledge and science which he puts in the center of the intellectual world of his time ending revolution started by Aurelius Augustine (354-430) from Thagaste in north Africa: Church included in itself all aspects of society and had answers to all important questions. In that way Isidore became known as the teacher of the Middle Ages and his work became an unavoidable manual in medieval schools for almost 800 years. Isidore discussed similar subjects in his work De rerum natura with emphasis on astronomy, cosmography and meteorology. Perhaps his work does not encompass ancient science in the best way, but it was obligatory in all important cathedral schools in the Middle Ages. When universities were founded in the 12th and 13th centuries their importance increased owing to translations from Greek and Arabic.

\subsection{Breeze of Cultural Renewal from the European West: the Venerable Bede.}

The fourth representative of this transitional period acted in a typically medieval community: British Venerable Bede $(672$ - 735) He was a monk, father of the English historiography and one of the greatest erudites of his time in Europe. Athough he spent all his life in the monastery in Northumbria, he knew classical 
authors and works of the church fathers, he spoke all important languages (Latin, Greek, Hebrew). His works represent a sort of scientific encyclopaedia in which all knowledges of the time were discussed: grammar, metrics, arithmetic, manner of making calendars with movable feasts with astronomic explanation of the process, natural phenomena of high and low tide and many other information and insights. Historia ecclesiastica gentis Anglorum (Ecclesiastical history of the English people) is considered to be his capital work as a true well of information about past times, particularly the process of Christianization of populations on the island.

\subsection{Carolingian Renaissance: Alcuin}

Mentioned four Christian intellectuals represent a kind of bridge between antiquity and Middle Ages - they were not only teachers of ancient knowledge but also creators and promotors of something new: all four attempted to save last remains of ancient culture and to give it to new generations; all of them wrote about the problems of antiquity and their time. There is another important characteristic connecting them: all four were born too late to give new life and vigour to the ancient culture as they wanted, but also too early to see fruits of their hard work.

Starting from the Carolingian Renaissance in the 8th and 9th centuries their example was followed by many other authors. We may mention for instance the British Alcuin (ca. 735-804) who contributed much to return of the ancient culture to monastery schools, then one of the deepest medieval philosophers Irish Johannes Scotus Eriugena (9th century), benedictine from Monte Cassino, Lombardian historian Paul the Deacon (Paulus Diaconus, ca. 720 - ca. 800) etc. They were well acquainted with the past, but they were not stuck in it nor were they its slaves, they prepared young generation for tasks which were ahead of them.

\subsection{Demographic and Cultural Awakening of Western Europe}

Decisive breakthrough in the renewal of society on new bases was made in Europe after the 10th century when Norman and Hungarian raids stopped which marked the end of semi-nomadism and Migration Period in Europe. More favourable political circumstances and possibility of work in greater security from outer enemies reflected favourably in all other fields. Owing to improvement of tools, planting new plants and intentional alternate growing of more useful crops, living conditions of the population started to improve. Increased yield of agricultural products enabled important demographic growth which led to liberating working force which filled the cities and affected favourably productive activity of entire population. In this period slavery disappeared so that rich classes of society started looking for economically profitable working methods and making what we presently call machines. In that way Europe started to recover and renew from its ruins scientifically, economically and culturally, and level of literacy and general culture was also increased with improved education.

First signs of this awakening could be noticed at the end of the 10th century when slow but constant economic progress was recorded which did not stop even during the crisis in the 14th century. This progress was primarily rural as land was the basis of not only economy but also the entire society. Many technical novelties were introduced. Iron plow was introduced instead of a wooden plow, as well as many other agricultural implements which improved soil tillage; food reserves were 
increased not only for family needs but also for selling to the city population. Progress was evident in expansion of arable surfaces (clearing land for cultivation and draining swamp areas) in two- or three-year alternate sowing with various kinds of cereals which resulted in considerable improvement of diet and living conditions in general. Europe of „,white bread“ and large consumption of meat was born, while Europe of „drink" was divided to northern part drinking beer and southern part where wine was consumed, with improved quality and quantity.

Awakening also referred to development of urban life. Moving of rural population to cities in search of work and better security resulted with founding new quarters for artisans and merchants. City life had to adjust to new needs. There was better organization and specialization of work, various artisans' and craft associations were formed etc. In areas where there were no cities particularly northern Europe new city settlements were formed particularly around larger monasteries or fortified castles of feudal dignitaries. In that way European cities were gradually turned into production centers and markets of a kind from which old city population profited immensely but also the ones leaving villages in order to liberate from social dependence on large land-owners. Naturally cities still depended on village and its food products just as village depended on city for their selling. Weekly fairs were organized, trade between cities and villages and cities between themselves developed, roads and bridges were built which contributed to stronger growth of economy which was reflected in increase of the production of commodities and growing barter between various categories of the city population and other cities and countries. Population started to abandon under-developed and unproductive agriculture in favor of craft and trade particularly with developed Near East wherefrom much demanded spices and consumer goods were imported which were forgotten in Europe from the Great Migration period. Monarchs and feudal aristocracy remelted their luxurious but useless silver objects into coins. This general progress was useful for all social classes who were organized because of the better work distribution. Faith in future and work was born.

Owing to this progress, European population also increased. According to the estimates it increased from 42 million to 46 million between the years 1000 and 1050, from 46 to 48 million between the years 1050 and 1000, from 48 to 50 million between the years 1100 and 1150 , from 50 to 61 million between the years 1150 and 1200 , and it reached 61 million between the years 1200 and 1250. In the moment when great plague broke out from 1346 to 1348 Europe probably had more than 80 million inhabitants. The plague is estimated to have killed about half of the European population in only two or three years.

Improved living conditions resulted in increased interest in science. Medieval scientific thought started with classification of everything surrounding a man and asking a series of questions: for instance why leaves on trees have different forms; why flowers and fruits have different colors; why a man must cook food; how are fish, birds, bugs conceived etc.

\subsection{The End of Long Cultural-Scientific Winter}

Gerbert from Aurillac (ca. 940 - 1003), teacher of the Emperor Otto II and future pope Sylvester II (999 - 1003) was a man who announced stronger cultural and scientific awakening of the West. He was a transitory person between the 
decadent period of the 10th century and renaissance of the following century. $\mathrm{He}$ spent several years (967-970) in Christian Catalonia where he was introduced with secrets of mathematical science under the direction of Atton, archbishop of the city of Vich. He was a universal scholar. He was interested in the works of old writers and he incited monks to copy them. He proposed harmony between religion and science believing that monks had to engage in scientific work in addition to faith. He read everything he could get and was not satisfied with comments but he looked for original Greek and Arabic works. As an encyclopaedic mind he wanted to know everything. Mathematics was a particular field of his interest which he learned on the basis of ancient models surpassing thereby all his contemporaries. He wrote about all or almost all scientific disciplines known at the time: logic, arithmetics, geometry, astronomy and music introducing important novelties into mentioned disciplines. His biographer monk Richer mentions that he was very skillful with astronomic instruments and that he drew orbits of the planets for understanding their movement. Instead of complex calculations about movements of planets and stars he made a globe of sky which illustrated their position at given time for his pupils. On a wooden sphere he drew constellations which he moved around marked pole on his model. He also constructed armillary spheres made of large circles divided to parallels (equator, tropic and polar circle) and ecliptic within which he hung planets with an ingenious mechanism. At the end of his mechanism he filled an empty circle with various tubes which enabled looking at poles and other important points of earth. Anyone could determine position of constellation by using these and some other devices as Richer emphasizes. With help of coin maker he made ,abacus” (calculating tool) which was divided into 27 fields lengthwise. He put nine figures on them representing all numbers. Alongside these numbers he had 1000 letters made and placed on the board getting in that way calculating device with which he could perform mathematical operations of multiplication and division with incredible speed no matter how large were numbers. It was announcement of increased interest for scientific researchwhich will incite many others to follow his example.

Progress was evident in many other fields of life. Burgundian monk and chronicler Rodulfus (Ralph) Glaber (985 -1047) was one of the most important witnesses of his time. He left an important testimony about the general enthusiasm at the beginning of the 10th century: „As the third year approached after the year 1000, it was evident in the entire country, and primarily in Italy and Gaul that church objects were renewed; although most of them were built well and renewal was not necessary, Christian communities competed in an attempt to have a more magnificent church than the neighbors. We may say that the world threw off its decrepitude and put on a white coat of churches. Then the believers renewed almost all churches of the bishopric sees, monastery churches dedicated to all known saints, and even small village chapels." It was only an outer sign of general social enthusiasm of the time.

\subsection{Beginning of the 2nd Millennium Marked by General Awakening}

Renaissance to which western European society was heading was formed, as all previous reformation movements, under the motto of „returning to the old“, i.e. to the „sources“. Diplomat and poet Pierre de Blois (ca. 1135 - 1203) wrote in relation with this: „One cannot easily cross from the darkness of ignorance to the scientific light, if he does not read works of old writers with greatest love! May dogs bark and pigs 
grunt, but I will not give up following the old. I will devote all my love to them and study them until the dawn of the day." This ,dawn of the day“ came as a consequence of all previous efforts to revive science and knowledge keeping antiquity in mind. This wish could not be crushed by the decadence caused by the collapse of the Carolingian Empire, nor all social and political turmoils at the end of the 9th and in the 10th century. Future events showed that this period was not dusk of previous social and cultural world but dawn of a new age firstly for western Europe, and then for the rest of the world. One of the great merits of the Carolingian Renaissance, and what Otto the Great did, was founding schools which made intellectual infrastructure for a similar cultural project in near future. Seed of knowledge and science which was sown in that period had to "hibernate" over the period of political anarchy and lack of stronger state support, until the „spring“ of better circumstances in the 12th century. History of medieval scientific thought was born gradually and developed within monastery walls and cathedral schools where texts of old authors could be found.

\subsection{Technical Transformation of Western Europe}

After the Great Migration period and all events at the time, building of new society had to start almost from the beginning. It was a difficult and gradual process, result of the initiative of the enlightened ones, usually anonymous individuals or rare organized groups. As working force was missing, man tried to exploit natural forces in a better way. Significant progress which was achieved, despite all difficulties, was the result of these small but frequent improvements. Owing to such circumstances the Middle Ages was quite a creative and innovative period despite the fact that everything had to start from the beginning and opposed to general belief about the Middle Ages. More than 200 inventions which are still used originated in the Middle Ages, starting from large things which will be discusssed later to „small“ but very important inventions such as buttons for clothes which enabled sewing much tighter and more practical dresses (skirts, pants, etc.) with save of expensive textile; table which enabled eating while sitting instead of lying on the left side; playing chess and cards and many other things which make human life pleasant, comfortable and „modern“. Lack or imprecision of historical sources prevents understanding of origin of many things and exact time of start of their use so we have to be satisfied with approximate assessment of their origin or period of creation. Most new populations which ruled largest part of Europe in the Early Middle Ages were warrior nomads who were in constant move in search of pasture for cattle. But once they abandoned (semi)nomadic way of life at the end of the Early Middle Ages they started to intensively develop agriculture which ensured better life conditions.

Roman agriculture before the Great Migration period was based on two- or three-year crop rotation which left soil to rest for a year every two or three years due to primitive soil tillage and insufficient fertilizing. Poor harvests caused inability of supporting not only of population but also of cattle. In this aspect the Middle Ages even aggravated existing situation particularly in northern countries with cold climate and various humidity degrees. These improvements were related with two fields: improvement of tools and improvement of system of soil tillage. First manual tools were improved as a consequence of village crafts, and then unsupported plow which was dominant in the Mediterranean countries. It was a kind of pole with a point hardened in fire or with an iron point which could only scratch the surface in light 
and dry soils. Harder soil was turned with a hoe and spade. Then there was plow with wheels and plowshare which could penetrate soil deeper without burdening the animals that pulled it. Such tool enabled deep plowing and pulling out plants with deep roots on soil on fallow. Plow with wheel was a heavy and expensive device which demanded several oxen for pulling. Earliest iron plowshare was found near the old Russian city of Ladog, and it originates from the 7th or 8th centuries. The Franks brought such plow with wheels from Germania to northern Gaul. Harrow cut the soil, turned it and covered grass and fertilizer. As it seems it was first used in Flandria.

All these improvements contributed to increasing significanty the yields of fields sown with barley, rye, oats, wheat etc., ensuring richer and more diverse food for humans and animals. Yields from fields tilled in that way were not particularly rich but they still represented significant improvement: in France and England they reached 4 to 6 times on one unit of sown seeds. Increased production of oats supported horse breeding which was related with economical shift of feudal cavalry. Horse was also used in agricultural works. His speed was greater than the oxen's which enabled more frequent plowing and greater yields.

Alongside these improvements first works about agriculture were written. Some of them originate from the 13th century. First work of the kind in England was Dite Hosebondrie by Walter de Henley (ca. 1250) one of the first English agronomists who wrote in French. In northern Italy Pietro de Crescenzi also known as Pier Crescenzio (1233-1320) who is considered to be the best western European agronomist in the Middle Ages wrote a work Ruralium commodorum opus libri XII around 1350. In this work he discussed agricultural techniques, way of tillage and tending gardens. It was immediately translated into Italian so it affected widely known gardens of aristicrats from Tuscany.

There were improvements in other fields as well. Channels and embankments in swampy and flooding areas appeared in Flandria in the 13th century and introduction of a windmill enabled pumping out of water and its throwing out of the embankment which resulted with drying of swamps as a source of mosquitos transmitting malaria. As opposed to this irrigation enabled tillage of dry areas in different parts of Europe. Most important achievement of the kind was the grand canal (naviglio grande) in Lombardia made at the end of the 12th century and first half of the 13th century which enabled drainage of water from Lago Maggiore from 35000 hectares of land. Such canals were regional traffic connections for transport of people and heavy loads which was useful in building larger objects, palaces, castles and churches.

Excellent roads which were once built by the Romans were devastated during the Great Migration period. Since they were built by slaves and non-Roman populations, the Romans needed not look for other sources of energy. Practice that defeated populations were turned into slaves was abandoned more and more with Christianization of new populations. Although slavery was not abolished fully, Christianity insisted on protection of dignity of each human being which forced winners to find other solutions for soil tillage, road building and maintenance or starting production.

Limited to its own human forces, medieval Europe started to learn how to use better other sources of energy. Many novelties were introduced in better use of horse equipment: hobnailing horses seemed to start in Byzant giving them better foothold and increasing their efficiency in pulling carts; use of saddle and stirrup enabled 
easier use of the animal and provided better stronghold for a horseman in a fight which made a horse true „war machine“ acquiring new dignity and enabling incredible development of feudal cavalry. Greatest progress was made with new way of harnessing: new equipment was no longer put around the neck of the animals which suffocated them and reduced their power, now horses were harnessed at their chest and oxen with their horns. Introduction of certain changes of pulling equipment enabled harnessing several horses one after the other which increased the strength of the team. All this increased significantly traction power of horses and transport of bigger loads which was used particularly in imposing Romanesque and Gothic cathedrals, castles and other buildings. Sculptures on the Laon cathedral recorded use of oxen and new means of transport in its building.

Many technical novelties were introduced in land transport as well. Instead of two-wheel carts which could take at most $500 \mathrm{~kg}$, cart with four wheels started to be made and their transport capacity was several times bigger.

Although water had always been used for various purposes, water-mill was a Mediterranean invention for grinding grains realized at the beginning of the Christian era. It did not develop further due to abundance of water sources and numerous slaves. Different social relations in the Middle Ages and greater need for sources of new energy turned a mill into a genuine machine. After technical invention of turning round movement into vertical, foot-powered potter's wheel was invented, and watermill became a sort of pneumatic machine for cutting, drilling, forging, crushing iron ore, production of paper etc. In the 12th century hydraulic saws appeared which facilitated wood processing, draining swamps, cutting forests for land clearance etc. On paintings from that time preserved in churches we can frequently see other technical devices and tools such as winch or lift for heavy loads etc.

Techniques of weaving and wool spinning are related with better use of water: loom with a footrest was mentioned in historical sources from the 12th century and spinning wheel mentioned somewhat later. Rolling of wool fabrics became easier in almost entire Europe when mills were intoduced. Mechanical mill for silk weaving appeared in Italy in the 13th century wherefrom it spread to other regions.

Origin of wind-mills has been studied less than the origin of water-mills. It seems that they were originally from Iran and that they came to Europe through Arab mediation. Starting from the 10th century they were used in Catalonia, on Greek islands and other countries in the Mediterranean which did not abound in precipitation so water-mills were useless. At the end of the 12th century in northern France and England wind-mills are mentioned as wind-powered mills. Inventory of a farmer from the middle of the 13th century was preserved mentioning tools driven by water- and wind-mills. In that period in north-eastern Europe where water and winds were abundant, mill with horizontal axis appeared. In order to turn wings in the direction of the wind, mill was placed high on large wooden tripod on which it could turn owing to special device.

Wind was used even more in sailing. However its variability and strength were not favourable for its use. Throughuot Middle Ages shipbuilders attempted to find compromise between boats with oars and boats with sails which led to building of a new type of ship - galley which used oars and wind as driving force. It seems it was first used in Byzant, but Italian shipbuilders constantly improved it so that it became the best ship in the Mediterranean in the 13th century. Things were different in the 
European north. Scandinavians developed special type of large sailboat which had angular keel because of which it had possibilities unknown to Mediterranean ships with much flatter bottom. Allegedly their leader Erik the Red discovered Greenland and reached coasts of North America on one of such boats. In time these characteristics were joined which resulted with building of famous Hanseatic, Basque and Portuguese ships. Larger ships were built having stern rudder attached to the back part of the keel instead of lateral oar-shaped rudder. Stern rudder was easily manipulative with a handle enabling easier, faster and securer steering. The oldest depiction of such rudder was preserved on a painting from the year 1180. Instead of rectangular sail in late antiquity triangular „lateen“ sail was introduced with a point downwards to enable sailing against the wind.

Invention of astrolabe revolutionized sailing. As the main navigational instrument astrolabe enabled measuring heights of planets and stars and graphical solving tasks from sphere astronomy. It was used until 18th century when sextant was invented. English Alexander Neckam (1157- 1217) described use of magnetic needle originally from China which enabled, alongside more precise nautical charts, European ships not to be limited to sailing along the coast and only in favourable seasons, but they could start their voyages throughout the year. From the end of the 15th century and beginning of the 16th centuries Europe had technique and ships which could reach any point on earth which led to increase of trade, transport, voyages and great geographical doscoveries which played crucial role not only in European but also in the world history.

Development of metallurgy in the 12th and 13th centuries was definitely very important regarding the aforementioned. Bellows stretched between two plates with a winch was used to produce stronger flame in processing ore containing silver. Such bellows in the 14th century led to opening numerous forges in which iron was forged and armors were made. Chain mail whose origin was in Persia in the period of Sassanid dynasty, spread to Europe over Byzant and Arabic world. Technique of casting bronze was improved for production of church bells and was used for production of the first firearms. Weapons were in great demand. English Franciscan Roger Bacon in 1294 described way of usage of gunpowder originally from China opening in that way epoch of production and use of firearms. It was first used in 1346 in centennial war between England and France first as heavy artillery and then around 1450 as personal military armament as a gun.

The same goes for the glass industry which had market due to many churches that were built. Increase of demand in the 12th and 13th centuries led to opening of many glass workshops in which painted glass (vitrail) for churches was produced serially. Center of the production was in Venice wherefrom it spread across Europe. The aforementioned Roger Bacon in 1294 left a description of spectacles (alongside description of firearms) as a revolutionary device for correcting defective vision which enabled many monks to continue copying manuscripts in their rooms with faint light of oil lamps. Owing to this invention scholars could continue their research and writing after their eyesight weakened. Guild of Venetian artisans announced regulations for making spectacles with convex glasses around 1300. Glass was also used as tool for scientific research.

In the area of basic building materials mostly wood, stone and iron were in use. Too intense use of wood was related with danger of frequent fires which could 
destroy not only family houses but also public buildings such as churches, castles and palaces. This was the reason to start using stone more. Building of an abbey in Chishire in England is a good illustration of intensive building at the time. In three years of building (1278-1281) from a quarry at distance of about $8 \mathrm{~km}$, total of 35 448 carts of stone weighing 35000 tons was transported reflecting strong development of architecture in the 12th and 13th centuries.

Digging of iron ore and iron processing were particularly developed in the 13th century Spanish iron" (iron from the Basque country) was highly esteemed. In 1296 customs in Castile recorded export of around 5000 tons. In Lombardy armors and weapons were produced and exported. Swedish iron was particulary highly esteemed in northern Europe. Trade with this material was controlled by the German Hansa. Iron and copper were extracted and traded with in Germany and Hungary. Bills of the building of the cathedral in Autun between 1294-95 in France show that iron made 10 $\%$ of all costs.

Demand for salt increased from the 12th and 13th centuries for salting meat and fish. It was the reason for opening numerous salt mines in northern Europe and sea saltworks in the south which improved technique of its extraction.

Novelties were introduced in other fields as well. In 1316 Italian physician from Bologna Mondino de Liuzzi (ca. 1270 - 1326) wrote an important work Anathomia in which he proposed dissection of human corpses for the needs of studying in university classes.

In 1445 German Johannes Gutenberg (ca. 1399 - 1468) introduced system of movable letters which we usually call printing press with which he revolutionized transfer of knowledge and culture making them accessible to wider public. Our knowledge particularly of about the ancient period would be far poorer without this invention.All this indicated that Europe left period of cultural and scientific recession which hit it after the Great Migration period and it took fast step towards the leading position which it retained until the two world wars in the 20th century.

This overview would not be complete if we left out Byzant which is inalienable part of Europe. It would take too much time and space to discuss everything that Europe and world owe to this culture and civilization. In the eyes of inhabitants of western Europe it was more a synonym of wealth and luxury than heir and representative of ancient cultural heritage. For instance they knew about various decorations in emperor's throne room such as roaring lions, singing birds and precious silk with which he supplied all important western European courts etc, but they did not know about his scientific and technical achievements. It is sufficient to mention revolutionary invention of "Greek fire“ which in a way anticipated modern war technique. Recipe for its preparation was highly confidential. It was invented by a certain architect Callinicos from Heliopolis (Baalbek) in Syria who escaped to Constantinople in the 7th century. According to a work Liber ignium ad comburendos hostes (On the Use of Fire to Conflagrate the Enemy) which was allegedly written by some Marcus Graecus from the 9th century this fire was made from sulphur, resin, oakum, oil and some other components. Petroleum enabled that this substance may burn on water as modern napalm. In naval battles it was thrown with long bronze tubes placed on the prow of the ship inflicting heavy losses to islamic Arabs on several occasions saving in that way Greek freedom and ancient culture. 
Many of the mentioned inventions were not created in Europe but they were accepted from other particularly eastern populations - Arabs, Persians, Indians and Chinese. Compass, astrolabe, paper, firearms are best examples. Paths which led them to Europe are not always clear. We have to emphasize that the Europeans knew how to recognize, accept and develop these things making them civilizational heritage of all others. But the fact is that Europe had to solve problems with ots own means which were characteristic of it and that before 14th century it possessed technical phenomena which surpassed outer acquisitions.

Impressed with great technical progress which transformed world a Cistercian from the famous Clairvaux monastery sang a hymn to mechanization in form of a prayer. After he lirically described benefits of the Auba river which drives many mills for grain and mills for beer and cloth production he exclaims: „Dear God, what comfort you provide to your poor people, not to be caught in great despair! How much you alleviate efforts of your sons who make penitence and save them from great efforts. How many horses, how many men would lose their strength in what this good river does providing us with food and clothes without our efforts! It coordinates its efforts with our own and after the work in hot sun it gets the only reward in peaceful flow after doing everything it was requested to do. After it makes numerous wheels rotate, she comes out in foam, seemingly grinding itself [...] In the end it is divided to numerous small hands which need its water to cook, sieve, mill, irrigate, raise or lower what would be impossible without it." The author of the mentioned hymn was a travelling artist and he travelled across a large part of Europe. He mentions that he encountered many technical novelties in various fields of life.

\subsection{Blooming of Art: Romanesque and Gothic Art}

Art in the Middle Ages also made great progress. This in particular refers to building churches in the 11th and 12th centuries conceived as a ,kind of huge reliquary in open space" which cannot be paralleled with edifices from antiquity. They were usually built with three or five naves divided with beautifully carved columns and chapels distributed around choir so that believers may come to altars on which certain saints were honored because of which pilgrims came from distant places. Central nave was usually covered with barrel vault reinforced with arches and lower lateral naves which often have cross vault ensuring stability. Interior is marked with dim light penetrating through narrow windows not to disturb inner concentration of a believer. Outer appearance of the churches, usually with a bell-tower of „lighthouse type“, is characterized by clarity and harmony of elongated horizontal lines. This was new Romanesque style which left many beautiful churches across Europe.

Construction technique which achieved extraordinary results in the 12th century with great edifices kept putting more difficult demands related with the statics and capacity of the object in front of the constructors. Architects soon realized that it was not possible to build such large buildings by simple increase and reinforcement of load-bearing points but that new methods of construction had to be invented suitable for coping with growing weight of new buildings. Result of these considerations was abandoning previous Romanesque architectural style and introducing special pointed arch resulting in Gothic architectural style which represented a genuine revolution in architecture. That was the birth of the Gothic style in north-western France (Îlle-de- 
France). Instead of previous heavy Romanesque buildings with thick horizontally oriented bearing walls and semicircular vaults and arches, much larger buildings with several naves were built in which slender columns made bearing skeleton which ended with a special construction key. Slender columns connected at the top took weight of the entire construction, emphasized dominance of the vertical and created impression of lightness and elegance. New style provided much greater bearing capacity of large buildings, domes, large public halls with bigger seating capacities. Therefore problem of the weight of bodies was studied at the end of the 12th and beginning of the 13th century. Magnificent Gothic cathedrals, aristocratic castles, city halls, palaces, monasteries, hospices, bridges and other public buildings were built which seem to defy gravity causing undivided admiration of an observer. In this context we can mention famous cathedral in the French city of Chartres, master-piece of high Gothic which represents a kind of wonder of medieval architecture and most independent stylistic expression of western European art after antiquity. It was built around 1140 with a bell-tower $105 \mathrm{~m}$ high. It was all great novelty. Perhaps never before, nor later, have so much technical innovations been introduced in architecture.

Development of architecture imposed new tasks to decoration as well. At the beginning sculpture followed Romanesque models but it also adapted to depiction of human figure in accordance with architecture. We can recognize attempt to make human figure authentic and close to believers. In the 13th century this decoration got its final form, very modest and natural. Painting was also encompassed with this development of architecture. Large space between slender and thin columns left enough space for high windows painted with Biblical and holy motifs turning them into a world of luminous paintings. This atmosphere was enhanced by wall paintings with Biblical depictions accompanied by images from nature which made cathedrals into colorful encyclopaedia from which people could learn about world and life. Gothic architecture in that way unified almost all kinds of arts and technical arts into a harmonious and homogenous whole.

Similar innovations were introduced in military architecture particularly after firearms were invented. Massive towers with deep ditches filled with water were built as early as the 11th century. From the 14th and 15th centuries they were built without blind spots in which invaders would be protected from the fire of defenders and that each place could be defended from the other place. Their round form and slanted inclination reduced power of enemy's blows. Defense also used numerous loopholes, openings for observation. Such improved fort enabled active defense which held enemy at safe distance.

In relation with Gothic architecture in the first half of the 14th century mechanical clocks started to be used, driven by gravity with hanging weights. From high church and city towers they determined rhythm of life by counting full hours and their parts so that citizens may have common measure of time.

Alongside increase of proportions of architectural monuments dimensions of construction sites and their organization also grew. Several masons and carpenters managed by a foreman or a monk were sufficient to build a small church in the late Middle Ages. As opposed to this at big construction sites of the 13th century specialization was necessary which in time yielded an expert called architect. His task was to project, supervise or run one or more construction sites because of which he was in high demand as an important person. He did not obtain his technical education 
on high schools as it was not taught there but he reached certain solutions with his intuition, on empirical basis and by using simple geometry and „secrets“ which certain architects kept jealously confiding only in their heirs and best or most trusting friends.

\subsection{New Evaluation of Mankind}

All this considerable progress of technical devices was a result of wish of a man to liberate from heavy physical labor and to improve production of life necessities but it was also a result of firm belief in progress. People in the Middle Ages tried to learn the language of Nature and its laws more intensively than we presently think. They learnt this lesson from antiquity but in some aspects they were even better than their teachers. Antiquity nurtured cult of liberal arts neglecting „unfree“ or mechanical arts letting slaves and people from lower social classes practice them. On the contrary Christianity condemned laziness and leisure believing that work was realization of human character giving it pronounced place in comprehension of human life. Biblical proverb: „Be fruitful and increase in number; fill the earth and subdue it.“ (Gen,1,28) was considered as an invitation to work and transformation of the world. Paul the Apostle instructs first Christians in Thessaloniki in Greece was very direct „shun any brother who conducts himself in a disorderly way..." and ,...if anyone was unwilling to work, neither should that one eat" condemning in that way pagan mentality which implied negative attitude to work. He worked as a saddler while in Thessaloniki not to burden his fellow-Christians.

Middle Ages realized by learning liberal arts how useful mechanical arts could be in all fields of life. The principle was not „one or the other" but „one and the other". In that way there was a synthesis of theory and practice, action and contemplation, intellectual and manual work.

Importance of theory and practice was emphasized in a special way by St. Benedict (ca. 480 - 547). He introduced principle ,pray and work“ (ora et labora) as a basic rule of life in a monastery. Similar rule was applied by Cassiodorus (485 583) who learnt his monks the value of manual work particularly of copying manuscripts of ancient legacy. Since then manual work was no longer considered humiliating for a free man but it was his obligation and blessing which was equated with prayer. Work got a completely new meaning. Monks started performing tasks with great enthusiasm which were previously done only by lower social classes. Larger, more beautiful and artistically more pleasing churches and cathedrals in Romanesque and later Gothic style were built having no models in ancient architecture. Gothic sculptures on many medieval cathedrals illustrate dialogue between contemplation and action i.e. free and mechanical skills. A new medieval man was born - eager, diligent and hard-working (homo faber industrius) who started to cut down forests and turn swamps into fertile fields, to make more perfect and complex tools and instruments, to build wider roads and longer bridges, higher castles and cathedrals, which gradually but persistently prepared later industrial revolution which changed not only the world in which a man lived but also the man himself who started to feel as the master of nature for the first time in history instead of its slave and toy of uncontrolled natural forces and laws. It was a true revolution not less significant than the one undertaken by the Greeks by introducing liberal arts. From this period there was increased awareness that free and mechanical arts must 
not be separated but that they complement one another, that they are interdependent, that the knowledge enlightens a man and work dignifies him and that only their uniform development can improve man and mankind. Thought should dignify work, and work should dignify thought. Culture and science must not be anyone's monopoly and education of all social classes should not decrease importance of an intellectual in the society. In that way mechanical arts owing to development of crafts gradually became just as important as the „liberal arts“. French Benedictines Honorius of Autun (ca. 1080 - 1157) and Hugh of Saint Victor (1096-1141) promoted synthesis of science and technics: „Learn everything and you will see that nothing is too much." In that way the humanism of the 12th century united encyclopaedic spirit and tendency towards the specialization of craft, arts and knowledge.

In other words, 12th century can be seen as an innovative period of the western civilization. Bishop of Chartres John of Salisbury († 1180) in the work Polycraticus returned dignity to all kinds of artisans who worked with cloth, wood, iron and other metals, as well as to peasants who worked in the fields, meadows and gardens. German cleric Gerhoch von Reichersberg (1092/93 - 1169) in the work Liber de aedificio Dei (God's workshop) wrote that this is ,a large workshop of the entire world which was a kind of cosmic workshop." In it man was affirmed as an artisan who shaped, reshaped and created something new; he was becoming working man (homo faber), producer, associate of the Creator and Nature.

If we understand the word ,science“" as use of reason to improve life conditions and understand world better we could say that modern science was born in time of Peter Abelard (1079 - 1142) who gave his son a very indicative name - Astrolabe, as an important astronomical device. Such kind of modernity is hardly imaginable presently.

\subsection{New Approach to Human Health: Medical Schools}

Medicine as an empirical discipline entered system of medieval scientific culture rather quickly. Isidore of Seville added medicine to the system of seven liberal arts. Too narrow framework of seven arts was expanded for the first time so that its development led to founding medical schools which became faculties in the 13th century. Other related or auxiliary disciplines started to gather around this core. Medicine as science is unimaginable without physiology or anatomy or natural sciences such as mineralogy, botany, zoology, chemistry, etc.

Strong impetus for opening medical schools in the Middle Ages came from opening hospitals during the Crusades within which medicine started to develop as a clinical discipline. Anesthesia with plants was used first in southern Italy where influences of the Christian West and Byzantine-Islamic East mixed. Contacts of these three worlds and cultures were particularly evident in the famous Salernitan School of Medicine (Schola Medica Salernitana) which was founded in the 10th century in southern Italian town of Salerno near Naples.

It became particularly famous with arrival of a physician Constantine the African (ca. 1015-1087) who travelled through countries of the Near East as a young man selling remedies and learning Arabic, Persian and Greek. After he became a physician, he mostly did theoretical medicine. Archbishop of Salerno and a physician Alfano helped him to translate many medical works from Greek and Arabic to Latin. 
Around the year 1070 he entered the Benedictine order in Monte Cassino where the educated abbot Desiderius (1058-1086), who later became Pope Victor III (1086 1087), let him work in favourable conditions. In that way abbey became central place for translating Greek and Arabic works. Due to his translations, West could meet forgotten Greek medical heritage and advanced works of Arabic scholars which represented turning point in history of European medicine.

Other doctors and translators worked together with Constantine in the Montecassino abbey such as Atto and Johannes Afflatius († 1003.). The latter continued translating tractate about fevers, and he also left behind Liber aureus de remediorum et aegritudinum cognitione (Golden Book of Understanding Remedies and Diseases). Owing to work of these people Salerno was called Civitas Hippocratica (city of Hippocrates) in which anatomy was practiced as well. Since dissections of human body were not introduced, anatomical research was performed on pigs whose structure was considered similar to the human. Surgery was also practiced. Perhaps the greatest importance of that school was its role as the first herald of new approach to medical science in western Europe due to its interest in basic works of classical antiquity and application of experimental methos in work of its physicians and researchers. Emperor Friedrich II Hohenstaufen moved it in 1231 to Naples ensuring continuation of its work within the university as a medical faculty. Association of magistri from Naples had the privilege of giving academic titles and licences (licentia) to the ones who attended lectures and passed exams. But candidates had to attend logic for three years by that time and five years of medicine in order to study Hippocrates and Galen and do one year of practice. Candidate for a physician after getting a written guarantee of his professors that he attended lecture regularly was supposed to take the exam in front of the professors in presence of king's officials who issued licence for work.

Salernitan school, cradle of old science, enriched with Greek and Arabic achievements and experiences obtained with surgical anatomy became a model for other similar schools. One of them was founded in the southern French city of Montpellier, trade center in the Mediterranean Sea and papal feud. Study of medicine is mentioned here from the year 1137. But this school became just as famous as the school in Salerno over the course of time. Similar schools were founded in Bologna and Paris where in the first half of the 13th century study of medicine - alongside philosophy, theology and law - was raised to the level of one of four "higher" faculties.

\subsection{Flower of Medieval Culture: University}

Creation of universities was related with renaissance of the cities and their new structure. Great demographic revival in the 11th century incited moving of rural population to cities where economic, social and political circumstances were much better. Such life conditions were made by their inner organization and division of labor which was favourable for creation of crafts and trade activities. City also meant freedom. Using force or compromises city managed to obtain certain political, legal and social autonomy from its feudal masters, particularly freedom of associating to protect its own interests. Members of certain associations (gilde, societas, universitas) were granted certain rights and conveniences, particularly possibility of free choice o their leaders, work programing, exemption from certain social 
obligations and interfering of city administration to works of the association (libertates, imunitates, privilegia).

In the process of stratification of the medieval society into different classes, alongside typical civil stratum, new category of citizens appeared which had promising prospects of future - intellectuals. Developed city life demanded not only specialized artisans and skillful merchants but also scriveners, notaries, accountants, lawyers and other literate workers. Therefore studying and teaching became a profession. In time intellectuals became a social class which as opposed to others did not base its power on feudal categories of nobleness of blood, descent or wealth acquired in trade, but on actual intellectual abilities of an individual and strength of its professional association. Gradually they became professionals of knowledge and protagonists of transformation first of the school system and then entire society. Urban intellectual was, jus as the artisans, member of a complex social community in which he performed socially useful work which demanded high qualifications. His consciousness was crucial regarding the fact that his professional and socially useful knowledge must not be kept to himself but that it has to be in circulation as merchants do with their commodities. That was the only way he could compete with other socially useful workers. School was his „workshop“ in which he ,produced“ and ,sold" knowledge as his specific product. All this had far-reaching consequences for the entire society and it led to a kind of „school revolution“.

Process of uniting of intellectuals i.e. school attendants started in Bologna. At the end of the 11th century school attendants or students (scholares or studentes) started joining certain regional clubs called „nation" (nationes) in which they could socialize and protect their interests. They achieved that their association was included in the city organism. Two such clubs, of the Italians and foreigners, away from their homes and without protection founded their own school associations (universitas studentium) which were supposed to protect them from unfair raising of prices of accommodation, food and other inconveniences. Students organized in that way threatened citizens who profited most from their stay in the city that they would leave the city massively if they continued to raise prices of accommodation and food. Since similar moves were recorded in other cities, citizens were forced to give in. It was better to reduce the price of renting a room than not to rent it at all. In that way student associations won the right to determine prices of accommodation and books necessary for the study.

After this victory over citizens, student associations aumed their „weapons” at other „enemies”, this time their professors. Their „weapons” was collective boycott of classes. Since professors particularly at the beginning lived from endowments and school taxes these threats had effect. Professors were forced to accept strictly determined rules of the ,game": they had to guarantee that they would provide quality classes for the money they received from the students; if they missed classes, unrealized lectures will be compensated; if he intended to travel somewhere he had to leave a deposit as an assurance that he would be back; if some professor missed lecture without reasonable cause he would pay fine; he had to pay fine if he could not gather at least five listeners at his lectures; his lectures had to start and end at the sign of bell; in his lectures he could not skip any chapters of the text intended for comments or postpone an answer to a question at the end of the lecture; that he would 
present thoroughly and quickly teaching material for each part of the school year; that he would not waste too much time on introductory lectures or bibliography etc.

After such students' demands professors also started founding their own associations (collegia). There were several conditions for joining these associations, such as taking a special exam in front of all professors (magistri or doctors) and approval of all members of professors' association. Candidate for a professor had to prove his ability to hold lectures, he had to take a standard exam, after which he was approved the right to belong to association of magistri (ad electorum corsortium magistrorum meruit attingere) and was a given a charter with testified that he had necessary knowlege for teaching at school (licentia ili venia docendi). This was the first academic stage or step (gradus acedemicus) which enabled advancing on the scale of university career and hierarchy. Third step of forming a university was founding common association of professors and students (universitas studentium et magistrorum) which was supposed to harmonize interests of both groups.

Paris saw similar course of events. As opposed to Bologna, magistri of theology and liberal arts held all power in their hands from the beginning and they were organized in an association of magistri and students (universitas magistrorum et studentium). In that way Bologna and Paris became models of associating of school attendants which served as model for all others. This is important for understanding university as an educational institution.

The greatest and most famous university center in the Middle Ages was undoubtedly Paris. Paris was a very lively intellectual center which was constantly developing and improving. Dialectic and theological speculation were studied in a special way as well as liberal arts and theology as fruits of miraculous expansion and deepening of humanistic culture which resulted with opening earliest faculties of philosophy and theology as two „most intellectual“ disciplines. This was the reason why young men from all parts of Europe started coming to Paris wanting to listen to lectures of the professors. Paris became international center of European culture and science as for instance papacy represented national character of medieval Christianity. Papacy and university are two terms which in a way represent universality of the Middle Ages and they were closely interrelated. Christianity gave general intellectual framework to European West, and lectures were held in Latin as an official language of the Catholic Church. These two institutions, religious and cultural, were effective and actual communities as opposed to political community represented by the Holy Roman Empire whose universality was more of theoretical than actual nature.

Immediately after these events old schools were reorganized and new schools were opened rapidly which played crucial part in shaping spiritual and intellectual physiognomy of the European continent. Schools were pioneers of European cultural and scientific unity.

At the beginning an intellectual was not considered much different than the artisans. An intellectual was in the center of great human construction site which resonated with sounds of tools of various arts and skills. He actually felt as a kind of artisan. He is an ,artisan of spirit“ and his „tools“ were intelligence and books. He was aware of social importance of his work and connection between science and school teaching. Therefore he did not lock his knowledge in the „chest“" but he let it 
circulate to make it available to a great number of people hungry of knowledge. He was the first who could use this benefit.

\subsection{Counterpoint of „Sacred“" and „Profane“ Sciences}

Taking into consideration time and circumstances when this happened, we could hardly expect that on the ruins of once powerful and advanced Roman Empire such a magnificent institution as university will be created in western Europe at the end of the 12th century. Over time university proved its vitality and importance as an axis and initiator of general progress. There had to be firm belief in ability of human reason to understand man and world around him to get the idea about university as „nourishing mother of science“ (alma mater studiorum) or „mother of sciences“ (parens scientiarum) as it was called in the Middle Ages with great tenderness and love. This was possible because European scholars similar to old Greeks learnt from one another without complex and prejudice enriching their insights with their own research and considerations. Their belief in the power of reason in discovering secrets of nature is best illustrated by the words of William of Chartres one of the leading representatives of the school in Chartres in the 13th century, that nature was an „collection of creatures" arranged after certain rules and principles comprehensible by a man. Albert the Great (1193-1280) added that nature was understandable (Natura est ratio) because it is a unique and logically created whole. He as a scholar who probably knew most about nature secrets in the Middle Ages, considered it to be a book written genially with a language of rational laws which a man as a rational being can and must learn how to read in order to progress.

If the beginning of the Middle Ages in central and western Europe was characterized by devastating everything, particularly school structure, its developed period was marked with renewal of what was ruined, and late Middle Ages offered new values. Legacy of this period is university as the most precious pledge of its attempts to rise from ruins which were a consequence of unfavourable historical circumstances. To tell the truth, antiquity left behind basic knowledge in many fields, but the Middle Ages had to search for them painstakingly and rediscover them in a certain way. In addition it developed consciousness that this knowledge cannot be anyone's property but that every generation has the right to learn them and an obligation to develop them, enrich them with new insights and transfer to others. Right to education became a general human attainment which changed image of the world regarding not only cultural and scientific but also social aspect. This changes stereotype about the Middle Ages as „dark“ period of human history perhaps more than anything else. Schools introduced much more light into society of the time and into comprehension of world and life than we can presently imagine. They contributed that the society which was stratified and divided may change with accelerated rhythm and class differences were reduced. This resulted in less important role of previous categories of descent and birth and knowledge became more distinct as general human category of which everyone has or can have some use. „Nobility after birth and blood“" was given heavy blow much before the French revolution and „nobility after book and knowledge“ was born which characterizes, relates and unites present-day world more than anything else. 


\subsection{Synthesis of the European Middle Ages: Humanistic and Technical Sciences}

As for the school program of the European universities we need to mention that until the 12th century school programs of all, conditionally speaking, high schools consisted of seven „liberal arts“. What could be learned in the schools of the time were quite scanty information and cognitions from the Latin grammar, rhetoric, logic and even scantier knowledge in arithmetic, astronomy, geometry and music. Between 1110 and 1200 previously unknown works by Aristotle, Euclid and Ptolemy came to western Europe as well as the scriptures of once famous Greek physicians, new arithmetic, Roman law texts etc. Instead of elementary theorems about triangle and circle, Europe finally had books in planimetry and stereometry; instead of difficult and complex mathematical operations with Roman numerals now one could use much simpler numbers which came to Europe from India through mediation of Arabs. All this contributed to appearance of new views anticipating future in the 13th century: birth of national languages, first significant successes in the field of technics, progress in observing nature and comprehending its secrets.

Owing to all this and other previously unknown insights, civilizational image of Europe started to change profoundly. Old schools of liberal arts became faculties of arts (facultates artium) at which good literary and scientific formation was obtained preparing young students for enrolling to the study or specializing three „higher” sciences: theology, law and medicine meaning that the notion of philosophy was much more complex than we think. Liberal arts were just integral parts of philosophy, not just philosophy. Narrow scope of profane knowledge which came down to seven liberal arts was broken and expanded with disciplines which did not belong to trivium and quadrivium before. This complex school apparatus changed several times, it was supplemented and improved, creating new professions, particularly academic associations which we call universities.

It is worth mentioning that school system in the Middle Ages was never quite unified because it was created gradually, under various cultural influences and views. It was difficult to determine which disciplines in the strict sense of teh word belonged to the program of teaching. Core of the teaching system were seven liberal arts. In time they started corresponding poorly to actual needs of the society so there were attempts to solve that shortcoming at various places, depending on actual needs of the society. Isidore of Seville added two new disciplines - medicine and law to the system of seven liberal arts which resulted in founding of medical and law schools which became faculties in the 13th century. Gradually other related or auxiliary disciplines started gathering around this core. Medicine as science is unimaginable without physiology or anatomy or natural sciences such as mineralogy, botany, zoology, chemistry, etc. The same goes for law, particularly Roman law which would be hard to imagine without knowing history and geography.

Philosophy and theology were the most important disciplines in the Middle Ages. The first one united „human sciences” (litterae humanae) or „profane“ arts and sciences, and the other „divine sciences“ (litterae divinae). However they were not strictly separated, or even less in opposition. They supported each other and therefore theologians as much as philosophers contributed to progress of culture and science. As strange as it may seem theologians in the Middle Ages were the greatest scholars who dealt with scientific work in the strict sense of the word, and even did 
experiments. Theology only seemingly is not related with philosophy and liberal arts. Philosophy and theology were considered as two „most rational“ disciplines, the latter borrowing many terms and interpretations from the former. After three years at the faculty of philosophy which was also known as faculty of liberal arts, student could enroll at some of three ,higher" faculties: theological, law and medicine. That is why many theologians were not only excellent philosophers who knew liberal arts well but they also practiced various natural and technical disciplines, and even experiments which opened new horizons new horizons anticipating new age. For instance Franciscan Robert Grosseteste (1168-1253), chancellor of the Oxford University and bishop of Lincoln developed theory of light as a generator of dimensions and totality of relations in all dimensions and directions. He was the first to describe complete process of a scientific experiment. Idea of a scientific spirit which was based on observation and experimenting was represented by many thinkers from the Middle Ages. Mathematics had an excellent representative in the person of merchant and mathematician Leonardo Fibonacci from Pisa (ca. 1170 1250) who introduced „Arabic“ (Indian) numerals. English Franciscan Roger Bacon (1214-1294) is considered as a pioneer of experimental method. Dominican Dietrich from Freiburg (Theodoricus Teutonicus, 1250-1310) became famous owing to his studies of the optics and natural philosophy. Other Dominican Albert the Great (1193-1260), professor at the Parisian university, gave significant contribution to progress of science with his sharp wit and depth with which he studied problems and phenomena. He was the first medieval integral thinker who achieved comprehensive synthesis of all fields of human knowledge of Greek, Roman, Jewish, Arabian and western European cultural heritage. His interest covered almost all scientific fields of the time: philosophy, theology, physics, chemistry, medicine, anthropology, zoology, botany, mineralogy, geology, astronomy, meteorology, mathematics, mechanics, climatology, cosmology, cosmography, architecture etc, without neglecting various practical skills such as weaving, sailing, husbandry, etc. Tradition ascribes him with construction of the first robot. „He studied and described entire universe, from stars to stones", in the words of German natural scientist G. Wimmer. Catalan Ramon Llull (1232 -1316) with his system of mnemonics and use of cylinder with words which could move in all directions, could be considered as a forerunner of modern computers. French theologian Nicolas Oresme (1323-1382) was the founder of analytical geometry which was later developed by René Descartes (1596 - 1650), he represented theory of Earth's rotation lying in that way foundations of scientific revolution which is usually thought to be initiated by Nicolaus Copernicus (14731543), Galileo Galilei (1564-1642), Johannes Kepler (1571- 1630), Isaac Newton (1642-1727), etc.

In other words idea of a scientific spirit which was based on observation and experimentation, as modest as it may seem presently, was proposed by many thinkers in the late Middle Ages. We must not forget that this idea marked beginning of enthusiasm which will only grow over time. Scientific revolution which went through full affirmation in the 16th and 17th centuries was formulated in its basic postulates in the Middle Ages. 
Krasic, S.: Humanistic and Technical Education in Antiquity and the Middle Ages

\section{Discussion}

From the 18th century Europe did not need help of other cultures and civilizations on its way from ruins into renewal of what was destroyed and later magnificent achievements. Finally it got universities as highest educational institutions, hearths of highest knowledge and civilization and science with which hardly any other institution could be compared, and European intellectuals from former disciples of previous cultures and civilizations made such progress that they started to excel their teachers and models. Many of them were aware of that. Papal documents of the time express pride and joy because of such situation. When mentioning universities, as opposed to many other subjects, they use elaborate vocabulary and poetic metaphors comparing them with ,rivers which water unfertile desert regions“, trees which give sweet and abundant fruits“; „high lighthouses“, „fertile fields with most excellent and outstanding crops“ etc.

Europe has every right to be proud of progress achieved in the Middle Ages but we must not forget that every progress is based on a series of complex factors which enabled it. Something never grew out of nothing. Every generation owes something one way or another to its predecessors just as every generation has an obligation of leaving the situation better than inherited. If it is true that Europe, and the rest of the world with it, got university in the Middle Ages as a peak of its development, of wellprogramed and institutionalized knowledge we must not forget that without ancient Greece and Rome, without patient work of so many generations of anonymous monks who copied this knowledge in their manuscripts closed in their modest rooms with faint light of oil-lamps, and enlightened minds of Boethius, Cassiodorus and Alcuin, to mention only some, probably we would never have knowledge that we presently have.

Regardless of the fact who contributed more to the development of European and world civilization, one thing is for sure: duty of every generation is to make everything in their power to leave the world behind less poor and primitive than it was. In that sense our generation also has something to be proud of, but we also have to be aware of our debt to other generations and civilizations. Nobody has measured size of moral debt which one individual has towards another, and even less the debt which one generation has towards he previous generations or one civilization towards the other. French Benedictine Bernard from Chartres in the 12 century expressed it with a beautiful metaphor:"We are like dwarfs on the giants' back. We can see better and further than them, but not because we have sharper vision or because we are taller than them, but because they lift us up and elevate us with their gigantic height."

\section{Conclusion}

Beginnings of knowledge are related with a man as a reasonable being and they are lost in the night of elapsed time. Science was born much later, in ancient Greece according to general belief, when a man started studying himself and world around him in a rational way in order to understand their nature and laws. Greeks were the first to turn knowledge to science, and to classify it into several groups which they called arts and found the most adequate way of its transfer not to lose it or make it absolute property of some individual or just one group. Due to historical 
circumstances the Romans took from the Greeks as their teachers schools and subjects learnt in them adding some new disciplines. This happened again in the Middle Ages when new European populations, particulary the Germani, took from the Romans not only their countries but also their cultural heritage, becoming not only conquerors but also their disciples and heirs. Historical development of schools and their programs was characterized with their constant improvement which led to founding universities in the 12th and 13th centuries when they became highest, best organized and institutionalized institutions. Universities were a typical European invention created as a result of medieval view of the world and man.

People in the Middle Ages tried to learn the language of Nature and its laws more intensively than we presently think. They learnt this lesson from antiquity but in some aspects they were even better than their teachers. Antiquity nurtured cult of liberal arts (artes liberales) neglecting „unfree“ or mechanical arts (artes mechanicae) letting slaves and people from lower social classes practice them. Middle Ages realized by learning liberal arts how useful mechanical arts could be in all fields of life. The principle was not „one or the other" but „one and the other“. In that way there was a synthesis of theory and practice, action and contemplation, intellectual and manual work. Since then manual work was no longer considered humiliating for a free man but it was his obligation and blessing which was equated with prayer. Work got a completely new meaning. A new medieval man was born - eager, diligent and hard-working (homo faber industrius) who started to cut down forests and turn swamps into fertile fields, to make more perfect and complex tools and instruments, to build wider roads and longer bridges, higher castles and cathedrals, which gradually but persistently prepared later industrial revolution which changed not only the world in which a man lived but also the man himself who started to feel as the master of nature for the first time in history instead of its slave and toy of uncontrolled natural forces and laws. It was a true revolution not less significant than the one undertaken by the Greeks by introducing liberal arts. From the Middle Ages there was increased awareness that free and mechanical arts must not be separated but that they complement one another, that they are interdependent, that the knowledge enlightens a man and work dignifies him and that only their uniform development can improve man and mankind.

\section{References}

Berve, G., - Hirmer, M. Greek Temples, Theatres and Shrines, London, 1969

Bloch, M., Lavoro e tecnica nel Medioevo, Bari, laterza, 1970

Bobin, L., La pensé grecque et les origines de l'esprit scientifique, Paris, 1923

Bolgar, R. R., Thae Classical Heritage and its Beneficiaries, Cambridge 1954

Bowra, C. M., Homer and his Foreunners, Edinbourgh 1955

---, The Greeck Experiance, London 1957

Clagett ,M., Greek Science in Antiquity, London, 1957

Cohen, M. R. - Drabkin, I. E. A., , A suurce book in Greek science, Cambridge (Mass.) 1966

Cook, J. M., The Greecks in Jonia and the East, London 1962

De Santillana, G. , Le origini del pensiero scientifico, Firenze, 1966

Dinsmoor, W., The Architecture of Ancient Greece, London, 1950 
Farrington, B.,, Greek science: its meaning for us, I-II, New York, 1944, 1953

Frajese, A., La matematica nel mondo antico, Roma, 1963

Fraser, P.M., Ptolemaic Alexandria, I-III, Oxford 1972

Frugoni, Ch., Medievo sul naso. Occhiali, bottoni e altre invenzioni medievali, Roma, Laterza, 2001

Fuhrmann, M.,, Das systematische Lehrbuch: ein Beitrag zur Geschichte der Wissenschaften in der Antike, Göttingen, 1960

Giacardi, L. - Roero S.C., La matematica delle civiltà anriche: Egitto, Mesopotamia, Grecia, Torino, 1979

Girard, P., L'Éducation athenienne, Paris 1891

Grant, E., The foundation of modern science int he Middle Age: their religious, institutional and intellectual contexts, Cambridge University Press, 1998

Grimal, P., The Civilisation of Rome, London, 1960

Heath, T. L., Aristarchus of Samos, the ancient Copernicus, Oxford 1966

Heath, T. L., A history of Greek mathematics, I-II, Oxford 1965

Heiberg, I., Geschichte der Mathematik und Naturwissenschaften im Altertum, München, 1925

Huxley, G. - Burn, A. R. - Baldry, H. C., The Birth of Western Civilisation (Greece and Rome), London 1964

Jäger, W., Paideia, die Formung der griechischen Menschen, Berlin 1936

Kirk, G. S., The Songs of Homer, Cambridge 1962

Krasić, S., Nastanak i razvoj školstva od antike do srednjega vijeka. Zadar 2012.

Lawrence, A, W., Greek Architecture, London, 1957

Le Goff, J., Das Hochmittelalter, Frankfurt am Main, 1965;

Histoire du developpement culturel et scientifique de l'umanité (Les grandes civilisations du moyen âge), III, Paris 1969

Marchis, V., Storia delle macchine. Tre millenni di cultura tecnologica, Roma - Bari, laterza, 2010

Marchis, V. - Nieddu, F., Materiali per una storia delle tecniche, Torino 2004

Marrou, H. I., History of Education in Antiquity, London, 1956

Neugehauer, O., The Exact Science in Antiquity, Copenhagden, 1951

Paré, G. - Brunet - Tramblay P., La Rennaisance du XII e siècle, les écoles et l'enseignement, refonte complète de l'ouvrage de G. Robert, Paris-Ottawa 1933

Rey, A., La science dans l'antiquité, I-V, Paris, 1942-1948

Robertson, D. S., A Handbook of Greek and Roman Architecture, Cambridge, 1943

Sabursky, S., The Physical World oft he Greek, London, 1956

Seznec, J., La Surviance des Dieux Antiques, London 1961

Singer, C. - Howard. E. J. - Hall, T. I., Storia della tecnologia, in „Le civilità medieterranee ed il Medioevo (circa 700 a. C. - 1500 d. C.). II, Torino, Boringhieri, 1962

Stahl, W. H., La cienza dei Romani, Bari 1974

Tarn, W., Hellenistic Civilisation, London 1952

Van der Vaerden, B. L. V., Science Awakening, Gröningen, 1954

White, L., Tecnica e società nel Medioevo, Milano 1967

Woods, T. E., How the Catholic Church built Western Civilisation, Regnery Publishing, 2005

Zeuthen, H.G., Die Mathematik im Altertum und im Mittealter, Leipzig, 1966 